ENVIRONMENTAL

RESTORATION

PROGRAM

\title{
Final Deactivation Report on the Tritium Target Facility, Building 7025, at Oak Ridge National Laboratory, Oak Ridge, Tennessee
}


This document has been approved by the ORNL Technical Information Office for release to the public. Date: $8 / 12 / 97$

ENERGY SYSTEMS 

ORNL/ER-406

\title{
Final Deactivation Report on the Tritium Target Facility, Building 7025, at Oak Ridge National Laboratory, Oak Ridge, Tennessee
}

Date Issued-August 1997

Prepared for the

U.S. Department of Energy

Office of Environmental Management

under budget and reporting code EW 20

Environmental Management Activities at the

OAK RIDGE NATIONAL LABORATORY

Oak Ridge, Tennessee 37831

managed by

LOCKHEED MARTIN ENERGY SYSTEMS, INC.

for the

U.S. DEPARTMENT OF ENERGY

under contract DE-AC05-84OR21400

\section{DISCLAIMER}

\begin{abstract}
This report was prepared as an account of work sponsored by an agency of the United States Government. Neither the United States Government nor any agency thereof, nor any of their employees, makes any warranty, express or implied, or assumes any legal liability or responsibility for the accuracy, completeness, or usefulness of any information, apparatus, product, or process disclosed, or represents that its use would not infringe privately owned rights. Reference herein to any specific commercial product, process, or service by trade name, trademark, manufacturer, or otherwise does not necessarily constitute or imply its endorsement, recommendation, or favoring by the United States Government or any agency thereof. The views and opinions of authors expressed herein do not necessarily state or reflect those of the United States Government or any agency thereof.
\end{abstract}





\section{DISCLAMMER}

Portions of this document may be illegible in electronic image products. Images are produced from the best available original document. 



\section{PREFACE}

This is the Final Deactivation Project Report on the Tritium Target Facility, Building 7025, at Oak Ridge National Laboratory, Oak Ridge, Tennessee (ORNL/ER-406). Although this element of work is not part of the Comprehensive Environmental Response, Compensation, and Liability Act of 1980, it was accomplished in accordance with the substantive requirements of the Act. This work was performed under Work Breakdown Structure 1.6.6.2.10.02, Activity Data Sheet 6504IS, "Isotopes Facilities Deactivation Project." This document provides the Environmental Management and Enrichment Facilities Program with the final report on the deactivation of Bldg. 7025. 



\section{CONTENTS}

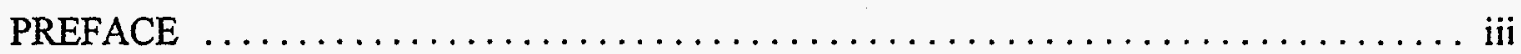

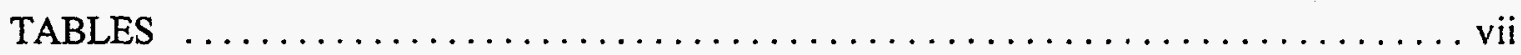

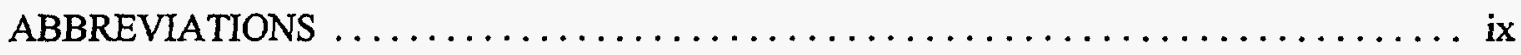

DEFINITIONS $\ldots \ldots \ldots \ldots \ldots \ldots \ldots \ldots \ldots \ldots \ldots \ldots \ldots \ldots \ldots \ldots \ldots \ldots \ldots \ldots \ldots \ldots \ldots$

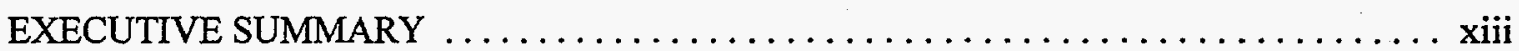

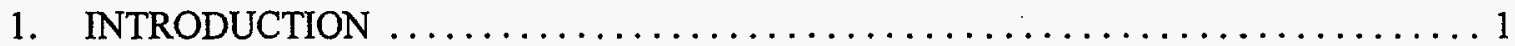

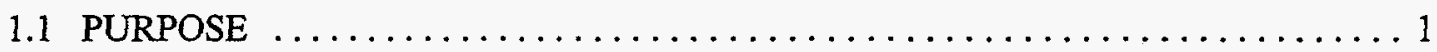

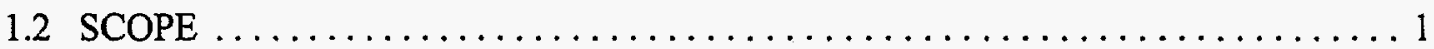

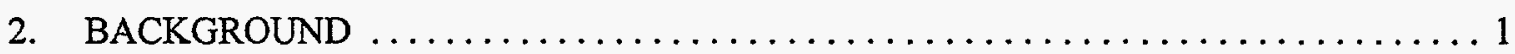

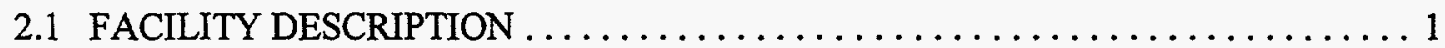

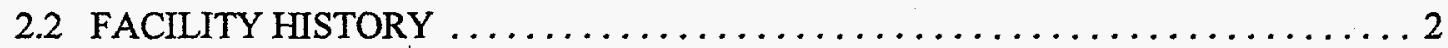

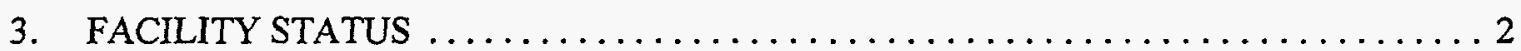

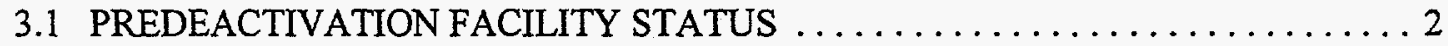

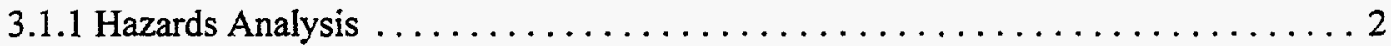

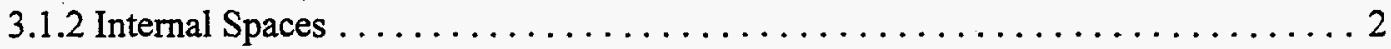

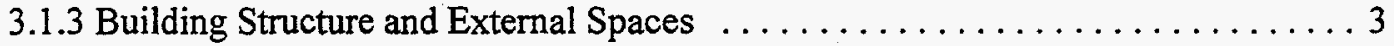

3.1.4 Process, Utility, and Support Systems . . . . . . . . . . . . . . . 4

3.1.5 Radioactive Material, Contamination, and Waste $\ldots \ldots \ldots \ldots \ldots \ldots \ldots$

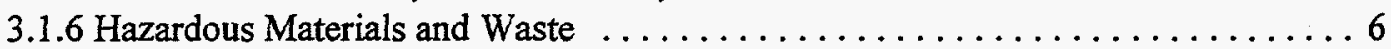

3.2 POST DEACTIVATION FACILITY STATUS $\ldots \ldots \ldots \ldots \ldots \ldots \ldots \ldots \ldots$

3.2.1 Deactivation End Point Completion $\ldots \ldots \ldots \ldots \ldots \ldots \ldots \ldots \ldots \ldots$

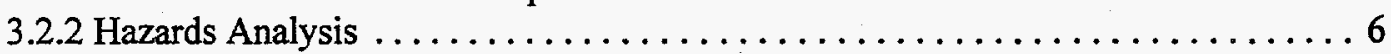

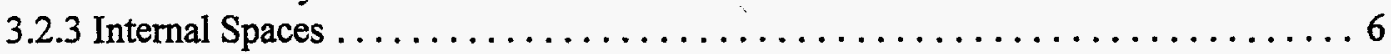

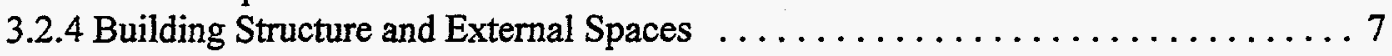

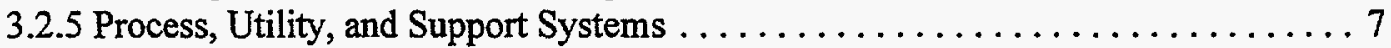



4. BUILDING 7025 DEACTIVATION ACTIVITIES $\ldots \ldots \ldots \ldots \ldots \ldots \ldots \ldots \ldots$

4.1 INTERNAL SPACES; ACCESS REQUIRED $\ldots \ldots \ldots \ldots \ldots \ldots \ldots \ldots \ldots \ldots$

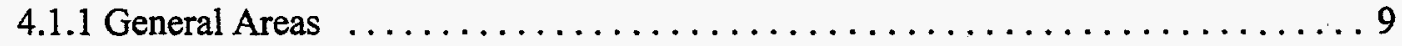

4.2 INTERNAL SPACES; NO ACCESS REQUIRED $\ldots \ldots \ldots \ldots \ldots \ldots \ldots \ldots \ldots$

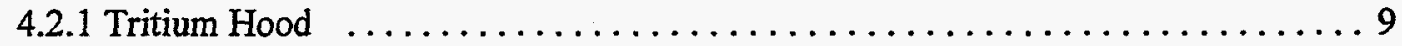

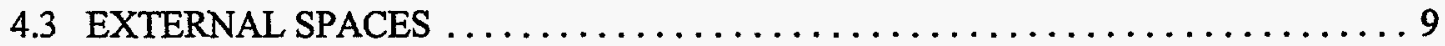

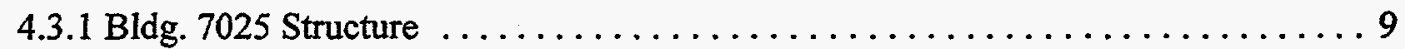

4.3.2 Bldg. 7025 Roof . . . . . . . . . . . . . . . . . . . . . . 9

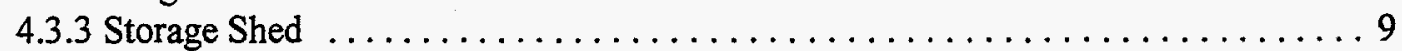

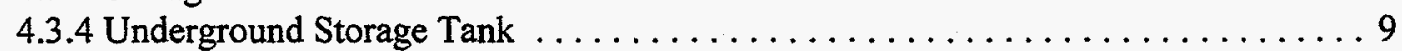

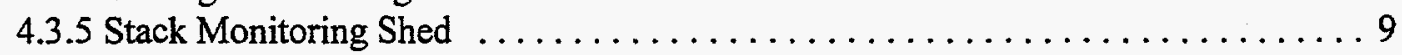




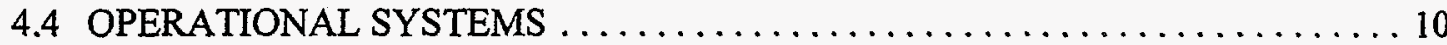

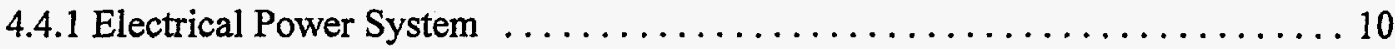

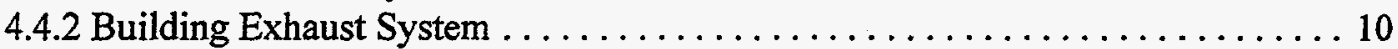

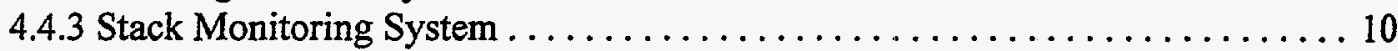





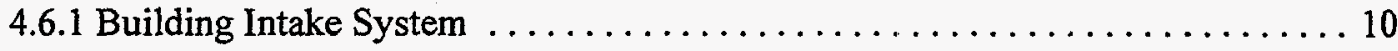

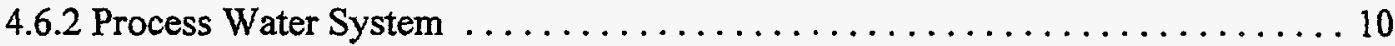



4.6.4 Process Gas System . . . . . . . . . . . . . . . . . . . . . 10

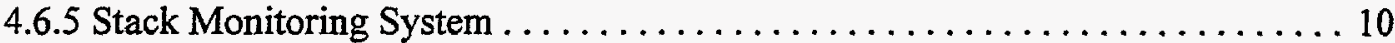



5.1 MEMORANDUM OF AGREEMENT $\ldots \ldots \ldots \ldots \ldots \ldots \ldots \ldots \ldots \ldots \ldots \ldots \ldots \ldots \ldots$

5.2 REQUTREMENTS AND COMMITMENTS $\ldots \ldots \ldots \ldots \ldots \ldots \ldots \ldots \ldots \ldots \ldots \ldots \ldots$

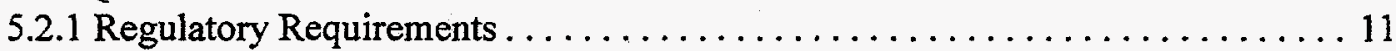

5.2.2 Stakeholder Commitments .......................... 11

5.3 POST-TRANSITION ACTIVITIES $\ldots \ldots \ldots \ldots \ldots \ldots \ldots \ldots \ldots \ldots \ldots \ldots \ldots \ldots \ldots$

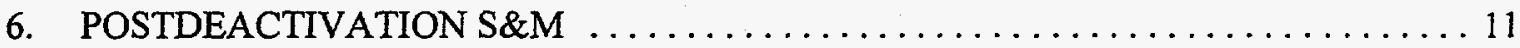

7. ABNORMAL ACTIVITIES/CONDITIONS $\ldots \ldots \ldots \ldots \ldots \ldots \ldots \ldots \ldots \ldots \ldots \ldots \ldots \ldots$

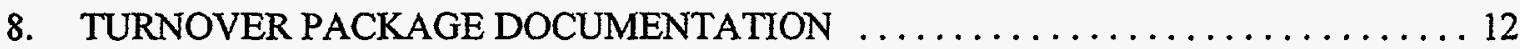

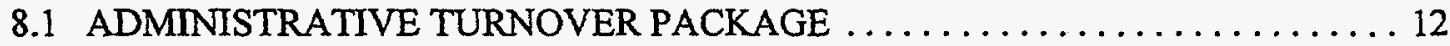

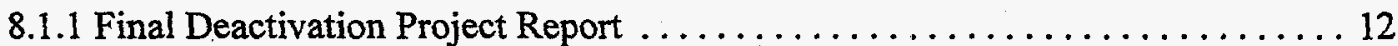

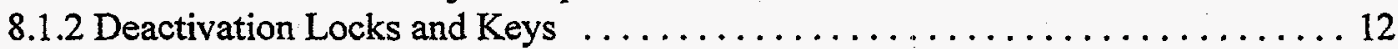

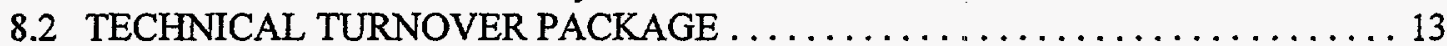

8.2.1 Updated Facility Drawings (Arrangement, PID, Loop, Etc.) . . . . . . . 13

8.2.2 "As Left" Photos of Spaces and Major Equipment . . . . . . . . . . . . 13

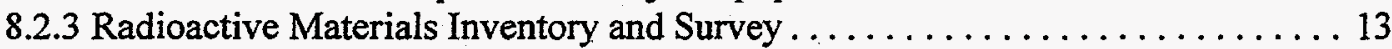

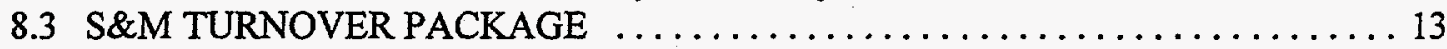

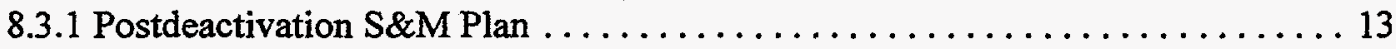

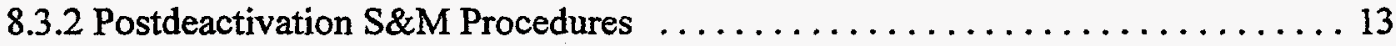

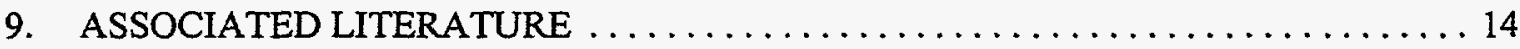

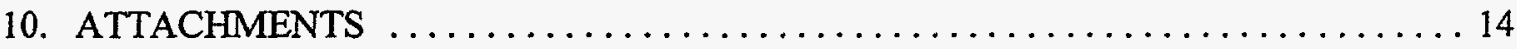

ATTACHMENT 1 BLDG. 7025 FLOOR PLAN ...................

ATTACHMENT 2 BLDG. 7025 PREDEACTIVATION FACILITY PHOTOGRAPHS . . . 2-1



ATTACHMENT 4 POSTDEACTIVATION FACILITY PHOTOGRAPHS $\ldots \ldots \ldots \ldots \ldots$ 4-1

ATTACHMENT 5 BLDG. 7025 RADIOLOGICAL SURVEY DATA . . . . . . . . . 5-1

ATTACHMENT 6 ADMINISTRATIVE TURNOVER PACKAGE CHECKLIST $\ldots \ldots$ 6-1

ATTACHMENT 7 TECHNICAL TURNOVER PACKAGE CHECKLIST $\ldots \ldots \ldots \ldots \ldots 7-1$

ATTACHMENT 8 S\&M TURNOVER PACKAGE CHECKLIST $\ldots \ldots \ldots \ldots \ldots \ldots \ldots$. 8 . 


\section{TABLES}

1. Predeactivation Radioactive Contamination Levels $\ldots \ldots \ldots \ldots \ldots \ldots \ldots \ldots \ldots 5$

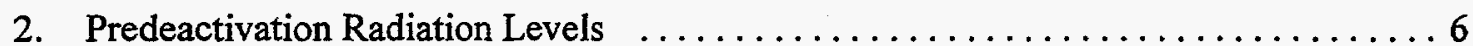

3. Bldg. 7025 Predeactivation Hazardous Materials and Waste ................. 6

4. Bldg. 7025 Predeactivation Hazardous Materials and Waste . . . . . . . . . . . . 8







\section{ABBREVIATIONS}

DOE

EM-40

EM-60

FDPR

MOA

ORNL

S\&M
U.S. Department of Energy

Department of Energy Office of Environmental Restoration

Department of Energy Office of Nuclear Materials and Facility Stabilization Program

Final Deactivation Project Report

Memorandum of Agreement

Oak Ridge National Laboratory

Surveillance and Maintenance 



\section{DEFINITIONS}

Commitments

Deactivation

Decommissioning

Decontamination

End Point

Stakeholder

Turnover Package
Tasks required to be accomplished to meet non-regulatory requirements. (site, stakeholders, etc.)

The process of placing a facility in a safe and stable condition to minimize the long-term cost of a S\&M program that is protective of workers, the public, and the environment until decommissioning is completed.

Refers to the ultimate disposition of a facility. Also substitutes for previously used "D\&D."

The removal or reduction of radioactive or hazardous contamination from facilities, equipment, or soils by washing, heating, chemical or electro-chemical action, mechanical cleaning or other techniques to achieve a stated objective or end condition.

A detailed specification for the final deactivation condition of areas and hardware within a facility and related documentation. An individual milestone towards the deactivation and/or the decommissioning of a facility.

Individuals and organizations (i.e. regulators, local municipalities, the public, etc.) who may be directly or indirectly impacted by activities associated with the IFDP. A compilation of project related documents to be given to a postdeactivation organization. 



\section{EXECUTIVE SUMMARY}

This report documents the condition of Bldg. 7025 after completion of deactivation activities as outlined by the Department of Energy Office of Nuclear Materials and Facility Stabilization (EM-60) Program guidance documentation. The report also outlines the activities conducted to place the facility in a safe and environmentally sound condition for transfer to the Department of Energy Office of Environmental Restoration (EM-40) Program.

This report includes a history and profile of Bldg. 7025 before and after completion of deactivation activities. This report also discusses turnover items, such as the Postdeactivation Surveillance \& Maintenance Plan, remaining hazardous materials, radiological controls, Safeguards and Security, quality assurance, facility operations, and supporting documentation provided in the EM-60 Turnover package.

Access to Bldg. 7025 will be necessary to facilitate the required S\&M activities to maintain the building safety envelope. Building 7025 was stabilized during deactivation so that only a minimal S\&M effort would be required to maintain its safety envelope when the building was transferred to the EM-40 program. Other than the minimal S\&M activities, the building will be unoccupied and the exterior doors locked to prevent unauthorized access. The building will be entered only to perform the required S\&M. 



\section{INTRODUCTION}

\subsection{PURPOSE}

This report documents the condition of Bldg. 7025 after completion of deactivation activities as outlined by the Department of Energy (DOE) Office of Nuclear Materials and Facility Stabilization (EM-60) Program guidance documentation. The report also outlines the activities conducted to place the facility in a safe and environmentally sound condition for transfer to the DOE Office of Environmental Restoration (EM-40) Program.

A history and profile of the facility before and after completion of deactivation activities are included. This report also discusses turnover items, such as the Postdeactivation Surveillance \& Maintenance Plan, remaining hazardous materials, radiological controls, Safeguards and Security, quality assurance, facility operations, and supporting documentation provided in the EM-60 Turnover package.

\subsection{SCOPE}

This report addresses the activities performed during deactivation associated with Bldg. 7025 to place the facility in a safe and environmentally sound condition to await decommissioning, the status of the facility, and the activities required to maintain the facility following deactivation. Attachment 1, "Building 7025 Floor Plan," illustrates the physical boundaries and scope of this Final Deactivation Project Report (FDPR). The scope of this FDPR is limited to Bldg. 7025.

\section{BACKGROUND}

\subsection{FACILITY DESCRIPTION}

Building 7025 is about 1.4 miles northeast of the central Oak Ridge National Laboratory (ORNL) site. It is within the perimeter fence of the ORNL 7000 area but is isolated from the main 7000 area buildings. The facility is a prefabricated metal-sided building with a total floor area of 590 $\mathrm{ft}^{2}$ and a total free space volume of approximately $6000 \mathrm{ft}^{3}$.

Tritium target fabrication equipment was housed in a 26-ft-long stainless steel hood, which was exhausted by a $2000-\mathrm{ft}^{3} / \mathrm{min}$ fan. The tritium hood exhaust was not filtered because no solid radioactive species were present in the air stream. A high vacuum evaporator system was used in the building for the preparation of uranium and thorium targets. The vacuum evaporator was operated in a high efficiency particulate air (HEPA)-filtered hood for contamination control. Only bench-top quantities of uranium and thorium were handled.

A forced air exhaust system (at the rear of the building) ran continuously in combination with a forced air intake system (at the front of the building) to prevent the buildup of any concentration of tritium gas in the occupied areas of the building. 


\subsection{FACILITY HISTORY}

Building 7025, which was a Tennessee Valley Authority surplus building, was installed in 1968 to house a tritium target fabrication system. It was programmatically funded into the early 1980 s by the Lawrence Livermore National Laboratory.

As a result of the overcrowding in Bldg. 3550 , the $\mathrm{ThO}_{2} / \mathrm{UO}_{2}$ evaporator was moved to building 7025 in the late 1970 s and was used to prepare hundreds of thin film oxide targets for a variety of customers around the world.

The building was used for fabricating titanium tritide targets, for preparing metallurgical samples for helium embrittlement studies by diffusing tritium into the samples and allowing it to decay to helium, and for preparing thin films of $\mathrm{ThO}_{2} / \mathrm{UO}_{2}$ by vacuum evaporation.

All tritium processing activities in this facility were halted in October 1989. All bulk tritium and the uranium storage traps have been removed from Bldg. 7025. Operation of the $\mathrm{ThO}_{2} / \mathrm{NO}_{2}$ high vacuum system was continued until January 1990.

\section{FACILITY STATUS}

\subsection{PREDEACTIVATION FACILITY STATUS}

Following approximately 22 years of operation and processing, Bldg. 7025 was surplused and many of the process systems were abandoned in place. General housekeeping was not maintained and the building's structural integrity was allowed to lapse.

Attachment 2, "Predeactivation Facility Photographs," contains photographs of the building conditions prior to deactivation activities. Attachment 3 lists drawings associated with Bldg. 7025 . No attempt has been made to verify the accuracy of these drawings.

\subsubsection{Hazards Analysis}

Based on the "SARUP Hazard Screening Document, Tritium Target Facility, Building 7025," HS/7025/F/RT-33, this facility is classified "RADIOLOGICAL" in accordance with DOE Standard DOE-STD-1027-92.

\subsubsection{Internal Spaces}

\subsubsection{General area}

The general area of Bldg. 7025 contained the operating consoles and control cabinets for the tritium processes and the uranium/thorium processes conducted in the building. In addition, the general area contained a desk and cabinets used in support of operating activities within the building.

Tables 1 and 2 list predeactivation radioactive contamination levels and radiation levels for these areas, respectively. 
Predeactivation hazardous materials and waste located in these areas are listed in Table 3, "Building 7025 Predeactivation Hazardous Materials and Waste."

\subsubsection{Tritium hood}

Except for mass spectrometric analysis, all tritium process activities were conducted in the tritium hood, a stainless steel hood on the south wall of Bldg. 7025. Six fire-retardant doors divide the hood into operating areas. Below the doors is a $10-\mathrm{cm}$-high by $8-\mathrm{m}$-long opening with movable shutters.

The tritium hood contained a hot sink for use in decontaminating process equipment. The hot sink drained to a $1500-\mathrm{L}$ underground storage tank, which was pumped to a low-level liquid waste (LLLW) system truck for disposal as necessary during the operational period of the building.

The tritium hood provided primary containment for the tritium process equipment. The hood was vented by the building exhaust system to a short stack adjacent to the building on the south side.

Tables 1 and 2 list predeactivation radioactive contamination levels and radiation levels for these areas. Table 3 lists predeactivation hazardous materials and waste located in these areas.

\subsubsection{Building Structure and External Spaces}

\subsubsection{Bldg. 7025 structure}

The exterior of Bldg. 7025 was inspected and found to be in generally good structural condition. The Bldg. 7025 structure and exterior provided secondary containment for the process equipment in conjunction with the building's roof. .

\subsubsection{Bldg. 7025 roof}

The roof of Bldg. 7025 was inspected and found to be in generally good structural condition, with the exception of air inleakage through various paths. The roof provided secondary containment for the process equipment in conjunction with the structure and exterior.

\subsubsection{Storage shed}

The storage shed adjacent to Bldg. 7025 is a pre-fabricated mobile shed that was used to store spare parts and materials used in the performance of process operations conducted in Bldg. 7025. The storage shed is not believed to be contaminated.

\subsubsection{Underground storage tank}

A 1500-L stainless steel tank is buried underground outside the east wall of the building. When the full operational level of the waste tank was reached, a liquid level gage was activated, and a visual signal was delivered inside the building. The tank contents were then pumped into a liquid waste disposal truck for disposal in the ORNL LLLW system.

The underground storage tank was emptied prior to deactivation and is assumed to be contaminated internally. The tank was filled with grout to prevent the accumulation of groundwater. 


\subsubsection{Stack monitoring shed}

The stack monitoring shed houses the detectors and equipment for monitoring the building exhaust system stack. The stack monitoring shed is adjacent to the stack and Bldg. 7025 on the south side of the building. The stack monitoring shed is assumed to be contaminated internally.

\subsubsection{Process, Utility, and Support Systems}

\subsubsection{Alpha hood}

The $\mathrm{ThO}_{2} / \mathrm{UO}_{2}$ process was conducted within the Alpha hood located in Bldg. 7025 on the east side of the general area. The alpha hood was independently exhausted by a 600 -cfm blower to the atmosphere.

The alpha hood and $\mathrm{ThO}_{2} / \mathrm{UO}_{2}$ process were only moderately contaminated due to process methodology and the small quantities of radioactive material processed.

\subsubsection{Building exhaust system}

Before deactivation, the building exhaust system provided ventilation services at $2000 \mathrm{cfm}$ to the tritium hood in Bldg. 7025. The building exhaust system for Bldg. 7025 is connected to a small stack, which was located on the south side of the building. The exhaust from the tritium hood was not filtered because no particulate contaminants were generated in the tritium process.

The building exhaust system is contaminated from the process activities performed prior to deactivation.

\subsubsection{Building intake system}

The building intake system provided positive air flow into the building as well as heating and cooling for the building's general area. The building intake system was not required for containment of the tritium process or the uranium/thorium process.

The building intake system consisted of a heating unit, cooling unit, evaporator, and blower. The heating unit, cooling unit, and blower were located on the north side of the building adjacent to the entrance, while the evaporator was adjacent to the west side of the building.

The building intake system is not believed to be contaminated.

\subsubsection{Stack monitoring system}

The stack monitoring system provided sampling and monitoring of the exhaust flow from the tritium hood. The stack monitoring system is primarily located in a shed adjacent to the Bldg. 7025 stack.

The stack monitoring system is believed to be contaminated as a result of process activities within the tritium hood. 


\subsubsection{Process water system}

Before it was deactivated, the process water system provided process water and cooling water to the processes conducted in Bldg. 7025. The process water system was fed from the potable water system through a backflow preventer. The process water system is not believed to be contaminated.

\subsubsection{Electrical power system}

Before deactivation, the electrical power system provided power and distribution for the electrical service to Bldg. 7025. Typical electrical loads were lighting, pumps, compressors, heaters, and exhaust fans. A 440-VAC system was used for the vacuum evaporators.

\subsubsection{Potable water system}

Before deactivation, the potable water system provided water to the Bldg. 7025 water fountain and lavatory and fed the process water system through a backflow preventer. The potable water system is not believed to be contaminated.

\subsubsection{Process gas systems}

Building 7025 used argon, nitrogen, and air for process activities and personnel contamination protection. The process gases were delivered to the building in pressurized cylinders, which were located outside the building. The argon and nitrogen were used in the process, while the air was used for positive pressure respirators as breathing air. All the cylinders have been removed and returned to the vendors.

The process gas systems are not believed to be contaminated.

\subsubsection{Radioactive Material, Contamination, and Waste}

Table 1 lists the radioactive contamination levels identified on radiation surveys conducted prior to deactivation:

Table 1. Predeactivation Radioactive Contamination Levels

\begin{tabular}{lll}
\hline \multicolumn{1}{c}{ Identification } & \multicolumn{1}{c}{ Description } & \multicolumn{1}{c}{ Quantity } \\
\hline General area & Alpha smear - transferable contamination & Up to $374 \mathrm{dpm} / 100 \mathrm{~cm}^{2}$ \\
General area & Tritium smear - transferable contamination & Up to $4673 \mathrm{dpm} / 100 \mathrm{~cm}^{2}$ \\
Tritium hood & Alpha smear - transferable contamination & Up to $43 \mathrm{dpm} / 100 \mathrm{~cm}^{2}$ \\
Tritium hood & Tritium smear - transferable contamination & Up to $7496 \mathrm{dpm} / 100 \mathrm{~cm}^{2}$ \\
Stack monitoring shed & Alpha smear - transferable contamination & Unknown \\
Stack monitoring shed & Tritium smear - transferable contamination & Unknown \\
Underground storage tank & Alpha smear - transferable contamination & Unknown \\
Underground storage tank & Tritium smear - transferable contamination & Unknown \\
Storage shed & Alpha smear - transferable contamination & Unknown \\
Storage shed & Tritium smear - transferable contamination & Unknown \\
\hline
\end{tabular}


Table 2 lists radiation levels identified on radiation surveys conducted prior to deactivation:

Table 2. Predeactivation Radiation Levels

\begin{tabular}{lll}
\hline \multicolumn{1}{c}{ Identification } & \multicolumn{1}{c}{ Description } & \multicolumn{1}{c}{ Quantity } \\
\hline General area & Fixed and transferable radiation levels & Less than $0.1 \mathrm{mRem} / \mathrm{hr}$ \\
Tritium hood & Fixed and transferable radiation levels & Less than $0.1 \mathrm{mRem} / \mathrm{hr}$ \\
Stack monitoring shed & Fixed and transferable radiation levels & Less than $0.1 \mathrm{mRem} / \mathrm{hr}$ \\
Underground storage tank & Fixed and transferable radiation levels & Less than $0.1 \mathrm{mRem} / \mathrm{hr}$ \\
Storage shed & Fixed and transferable radiation levels & Less than $0.1 \mathrm{mRem} / \mathrm{hr}$ \\
\hline
\end{tabular}

\subsubsection{Hazardous Materials and Waste}

Table 3 lists the hazardous materials and waste identified during facility walkdowns prior to deactivation:

Table 3. Bldg. 7025 Predeactivation Hazardous Materials and Waste

\begin{tabular}{lll}
\hline \multicolumn{1}{c}{ Identification } & \multicolumn{1}{c}{ Description } & Quantity \\
\hline Lead-based paint & Used as wall covering throughout building. & Indeterminate \\
PCBs & Electrical devices and transformers & indeterminate \\
\hline
\end{tabular}

\subsection{POSTDEACTIVATION FACILITY STATUS}

Attachment 4, "Postdeactivation Facility Photographs," contains photographs of the building conditions following deactivation activities.

\subsubsection{Deactivation End Point Completion}

End point criteria for deactivation activities and end point completion documentation are not applicable for Bldg. 7025. The requirements and guidance for these program elements were not developed prior to Bldg. 7025 deactivation.

\subsubsection{Hazards Analysis}

A postdeactivation hazard screening has not been performed for this facility. Therefore Hazards Screening HS/7025/F/RT-33, Rev. 0, remains the current hazard screening for the facility with a Hazard Level Classification for this facility of "radiological."

\subsubsection{Internal Spaces}

\subsubsection{General areas}

The miscellaneous items abandoned when the facility was no longer in use have been removed from general areas. No significant combustibles remain in the general areas.

The general areas of Bldg. 7025 were decontaminated to remove transferable contamination from access-required spaces. 
Postdeactivation radioactive contamination levels and radiation levels for this area are listed in Attachment 5, "Postdeactivation Radiological Surveys."

\subsubsection{Tritium hood}

All process equipment and debris have been removed from the tritium hood. The tritium hood was decontaminated to remove transferable contamination from the surfaces.

Postdeactivation radioactive contamination levels and radiation levels for this area are listed in Attachment 5, "Postdeactivation Radiological Surveys."

\subsubsection{Building Structure and External Spaces}

\subsubsection{Bldg. 7025 structure}

The exterior of Bldg. 7025 was inspected and found to be in generally good structural condition. The building exterior has been sealed to eliminate air inleakage and to provide an effective containment for the building.

\subsubsection{Bldg. 7025 roof}

The roof of Bldg. 7025 was inspected and found to be in generally good structural condition. The building exterior has been sealed at the lower levels in an attempt to keep small animals from entering the building.

\subsubsection{Storage shed}

The storage shed remains in place and abandoned. No decontamination has been performed. Contaminated materials were not stored in this shed.

\subsubsection{Underground storage tank}

The underground storage tank remains in place and abandoned. No decontamination has been performed.

\subsubsection{Stack monitoring shed}

The stack monitoring shed remains in place and in use. No decontamination has been performed.

\subsubsection{Process, Utility and Support Systems}

\subsubsection{Alpha hood}

The alpha hood has been disassembled and removed from the facility.

\subsubsection{Building exhaust system}

The building exhaust system has been shut down and abandoned in place. The tritium hood exhaust system remains in use to minimize the spread of tritium contamination to the facility. 


\subsubsection{Building intake system}

The building intake system has been isolated, de-energized, and abandoned in place.

\subsubsection{Stack monitoring system}

The stack monitoring system has been deactivated and abandoned in place.

\subsubsection{Process water system}

The process water system has been isolated, drained, and abandoned in place.

\subsubsection{Electrical power system}

All electrical services, with the exception of lighting, have been disconnected or de-energized at the main breaker box.

\subsubsection{Potable water system}

The potable water system has been isolated, drained, and abandoned in place.

\subsubsection{Process gas systems}

The process gas systems have been isolated, drained, and abandoned in place.

\subsubsection{Hazardous Materials and Waste}

Table 4 lists the hazardous materials and waste identified during facility walkdowns following deactivation:

Table 4. Bldg. 7025 Predeactivation Hazardous Materials and Waste

\begin{tabular}{lll}
\hline \multicolumn{1}{c}{ Identification } & \multicolumn{1}{c}{ Description } & \multicolumn{1}{c}{ Quantity } \\
\hline Lead-based paint & Used as wall covering throughout building. & Indeterminate \\
PCBs & Electrical devices and transformers & Indeterminate \\
\hline
\end{tabular}

\section{BLDG. 7025 DEACTIVATION ACTIVITIES}

The following section addresses the major activities performed during the deactivation of Bldg. 7025. The objectives of deactivation were to place the facility in a passively safe and environmentally stable configuration that can be efficiently and cost- effectively maintained for an indefinite period. The major deactivation issues, with regard to Bldg. 7025, are listed below. 


\subsection{INTERNAL SPACES; ACCESS REQUIRED}

\subsubsection{General Areas}

All storage cabinets, desks, file cabinets and miscellaneous office materials were removed from the building. Some were green-tagged for reuse. The remaining items were disposed of.

Asbestos insulation on steam lines, etc., was not removed. The asbestos floor tiles were not removed and are not intended to be removed until facility decontamination and decommissioning.

The walls throughout the building are covered with lead-based paint. Peeling and flaking areas were repaired, but the remainder of the paint will remain as is. Paint condition is an inspection item in the surveillance and maintenance (S\&M) plan for Bldg. 7025.

\subsection{INTERNAL SPACES; NO ACCESS REQUIRED}

\subsubsection{Tritium Hood}

All process equipment and debris have been removed from the tritium hood, which was decontaminated to remove transferable contamination from the surfaces. The exhaust system for the hood remains in service to prevent spread of tritium contamination to the remainder of the building.

\subsection{EXTERNAL SPACES}

\subsubsection{Bldg. 7025 Structure}

The building structure was inspected and repaired, as necessary, to provide structural stability for the next 5 years. The building was sealed to provide an effective secondary containment boundary and to prevent animal intrusion to the interior during the postdeactivation S\&M period.

\subsubsection{Bldg. 7025 Roof}

The building roof was repaired and sealed, as necessary, to provide an effective secondary containment boundary and to minimize the amount of water in leakage during the postdeactivation S\&M period.

\subsubsection{Storage Shed}

The storage shed remains in place and abandoned.

\subsubsection{Underground Storage Tank}

The underground storage tank remains in place and abandoned.

\subsubsection{Stack Monitoring Shed}

The stack monitoring shed remains in place and in use. 


\subsection{OPERATIONAL SYSTEMS}

\subsubsection{Electrical Power System}

All electrical services that were not essential to basic S\&M operations were disconnected at the main breaker box.

\subsubsection{Building Exhaust System}

The building exhaust system has been shutdown. The tritium hood exhaust system remains in use as a means of minimizing the spread of tritium contamination into or out of the facility.

\subsubsection{Stack Monitoring System}

The stack monitoring system has been shutdown and abandoned in place.

\section{5 "MOTHBALLED" SYSTEMS}

There are no "mothballed" systems associated with Bldg. 7025.

\subsection{ABANDONED SYSTEMS}

\subsubsection{Building Intake System}

The building intake system has been deenergized and abandoned in place.

\subsubsection{Process Water System}

The process water system has been isolated, drained, and abandoned in place.

\subsubsection{Potable Water System}

The potable water system has been isolated, drained, and abandoned in place.

\subsubsection{Process Gas Systems}

The process gas systems have been isolated, drained, and abandoned in place.

\subsubsection{Stack Monitoring System}

The stack monitoring system has been shut down and abandoned in place. 


\section{TRANSITION ACTIVITIES}

Building 7025 will be officially transferred from the DOE EM-60 program to the EM-40 program by a Memorandum of Agreement (MOA). The building will be accepted "as is" by EM-40 at the time of transfer.

\subsection{MEMORANDUM OF AGREEMENT}

The MOA documents the requirements agreed upon between EM-40 and EM- 60 . The signed MOA indicates acceptance by EM-40 that the criteria outlined in the MOA have been completed satisfactorily, with the exception of post-transition punchlist items, and that the level of deactivation of the facility is acceptable for transition to the EM- 40 program.

Post-Transition punchlist items will be finished after deactivation is complete. The details of how the punchlist items will be completed and documented will be addressed in the MOA.

\subsection{REQUIREMENTS AND COMMITMENTS}

\subsubsection{Regulatory Requirements}

There are no regulatory requirements associated with Bldg. 7025.

\subsubsection{Stakeholder Commitments}

There are no stakeholder commitments associated with Bldg. 7025.

\subsection{POST-TRANSITION ACTIVITIES}

No post-transition punchlist items have been identified for Bldg. 7025. All deactivation activities have been completed prior to transfer to EM- 40 .

\section{POSTDEACTIVATION S\&M}

The "Postdeactivation S\&M Plan for Building 7025" covers S\&M activities associated with the interior spaces, operational, and "mothballed" systems, and external areas related to Bldg. 7025.

The specific objectives of the S\&M program for Bldg. 7025 are as follows:

1. Ensure adequate containment of contamination,

2. Provide physical safety and security control,

3. Maintain the facility in a manner that will minimize potential hazards to the public, and 
4. Provide a mechanism for the identification and compliance with applicable environmental, safety, and health requirements.

The "Postdeactivation S\&M Plan for Building 7025" details the specific S\&M items to be performed.

The S\&M activities associated with Bldg. 7025 include the following types of activities:

- Walkdowns and inspections for structural integrity, safety, radioactive contamination, and hazardous material conditions;

- General housekeeping of the interior and exterior of the building as needed; and

- Maintenance activities required to maintain the security and safety envelop of the facility.

\section{ABNORMAL ACTIVITIES/CONDITIONS}

No abnormal activities/conditions have been identified for Bldg. 7025.

\section{TURNOVER PACKAGE DOCUMENTATION}

\subsection{ADMINISTRATIVE TURNOVER PACKAGE}

Administrative turnover consists of a collection of administrative documents. This includes procedures, agreements, permits, and other documents not directly related to the physical facility. The level of detail depends on the conditions, requirements, and agreements specific to the facility. Attachment 6, "Administrative Turnover Package Checklist," reflects the documents required for this facility with respect to administrative turnover. The following sections detail the contents of the applicable sections required for the facility.

\subsubsection{Final Deactivation Project Report}

The FDPR is a management summary of the facility deactivation completion, general status, and conditions, demonstrating conformance with DOE's specification of the overall end point. It identifies management actions needed that are not routine. Unresolved issues are also described.

\subsubsection{Deactivation Locks and Keys}

The only locks used in Bldg. 7025 are the one securing the door at the front of the building and the one securing the adjacent storage shed. 


\subsection{TECHNICAL TURNOVER PACKAGE}

Technical turnover consists of a collection of technical documents that describe the facility, its equipment, and the conditions at the completion of all deactivation activities. The level of detail depends on the conditions, requirements, and agreements specific to the facility. Attachment 7 , "Technical Turnover Package Checklist" reflects the documents required for this facility with respect to technical turnover. The following sections detail the contents of the applicable sections required for the facility.

\subsubsection{Updated Facility Drawings (Arrangement, PD, Loop, etc.)}

These are facility, room, and cell arrangement drawings - to the extent they exist. However, except in unique circumstances, as-builts of the deactivated conditions within the facility are not provided.

\subsection{2 “As Left" Photos of Spaces and Major Equipment}

These are description/photos of spaces for which access is not anticipated during S\&M.

\subsubsection{Radioactive Materials Inventory and Survey}

The inventory lists radioactive and fissile material remaining as contamination with characterization information.

The survey lists final radiological/hazardous materials survey records, final configuration and S\&M requirements, available drawings, specifications, procedures, manuals, and unplanned occurrences records applicable to the facility.

\subsection{S\&M TURNOVER PACKAGE}

S\&M turnover consists of a collection of documents required to support Postdeactivation S\&M activities. The level of detail depends on the $S \& M$ specific to the facility. Attachment 8, "S\&M Turnover Package Checklist" reflects the documents required for this facility with respect to S\&M turnover. The following sections detail the contents of the applicable sections required for the facility.

\subsubsection{Postdeactivation S\&M Plan}

This document describes the S\&M plan for the facility after deactivation is complete, up to the initiation of decommissioning. The S\&M activities will be integrated into the decommissioning work and phased out as decommissioning is completed.

\subsubsection{Postdeactivation S\&M Procedures}

Table 5 contains a list of procedures required during the postdeactivation S\&M period. These procedures outline the maintenance activities and special surveillances required to ensure that the facility conditions and safety envelope remain consistent until decommissioning can take place. 
Table 5. Bldg. 7025 S\&M Procedures

\begin{tabular}{cc}
\hline Number & Procedure Title \\
\hline IP-402 & Bldg. 7025 Check Sheets \\
\hline
\end{tabular}

\section{ASSOCIATED LITERATURE}

\author{
Document Number \\ Draft \\ Draft \\ DOE/EM-0246 \\ ORNL/ER-249/R2

\section{Docunnent Title} \\ Facility Deactivation End Points Handbook; Volume 1: \\ Method and Examples. \\ Facility Deactivation End Points Handbook; Volume 2: \\ Deactivation Practices. \\ Decommissioning Resource Manual. August 1995 \\ Martin Marietta Environmental Restoration Program; \\ Work Plan for the Isotopes Facilities Deactivation \\ Project at ORNL, August 1995 \\ ORNL; Local Emergency Manual, Isotope Area, \\ Revision 94-1, January 1994
}

\section{ATTACHMENTS}

1. Bldg. 7025 Floor Plan

2. Bldg. 7025 Predeactivation Facility Photographs

3. Bldg. 7025 Drawing List

4. Bldg. 7025 Postdeactivation Facility Photographs

5. Bldg. 7025 Radiological Survey Data

6. Administrative Turnover Package Checklist

7. Technical Turnover Package Checklist

8. S\&M Turnover Package Checklist 
ATTACHMENT 1

BLDG. 7025

FLOOR PLAN 

ORNL DWG 97C-256

\section{Building 7025}







\section{ATTACHMENT 2 \\ BLDG. 7025 \\ PREDEACTIVATION FACILITY PHOTOGRAPHS}





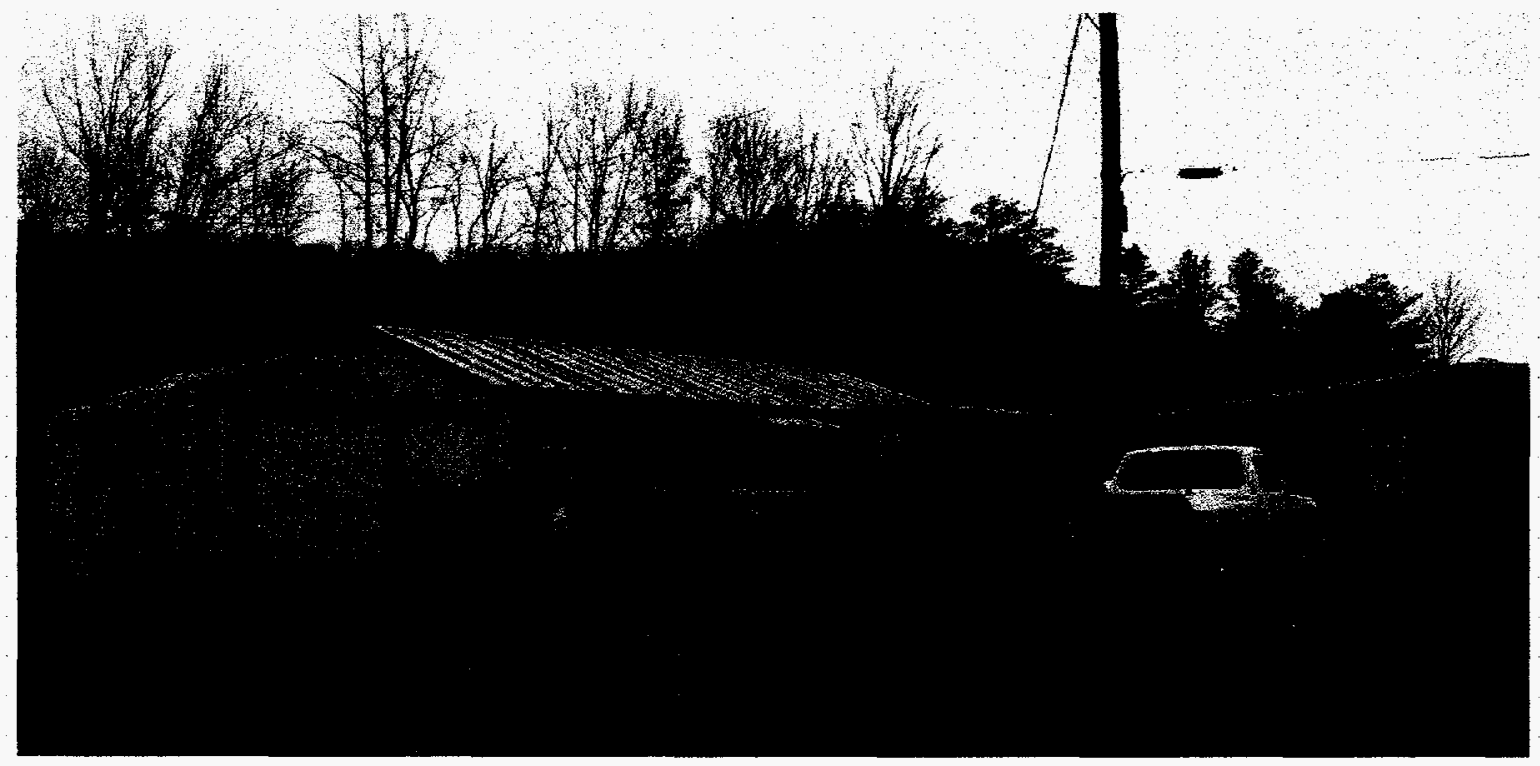

Fig. 1. View of Bldg. 7025 and the adjacent storage shed. 


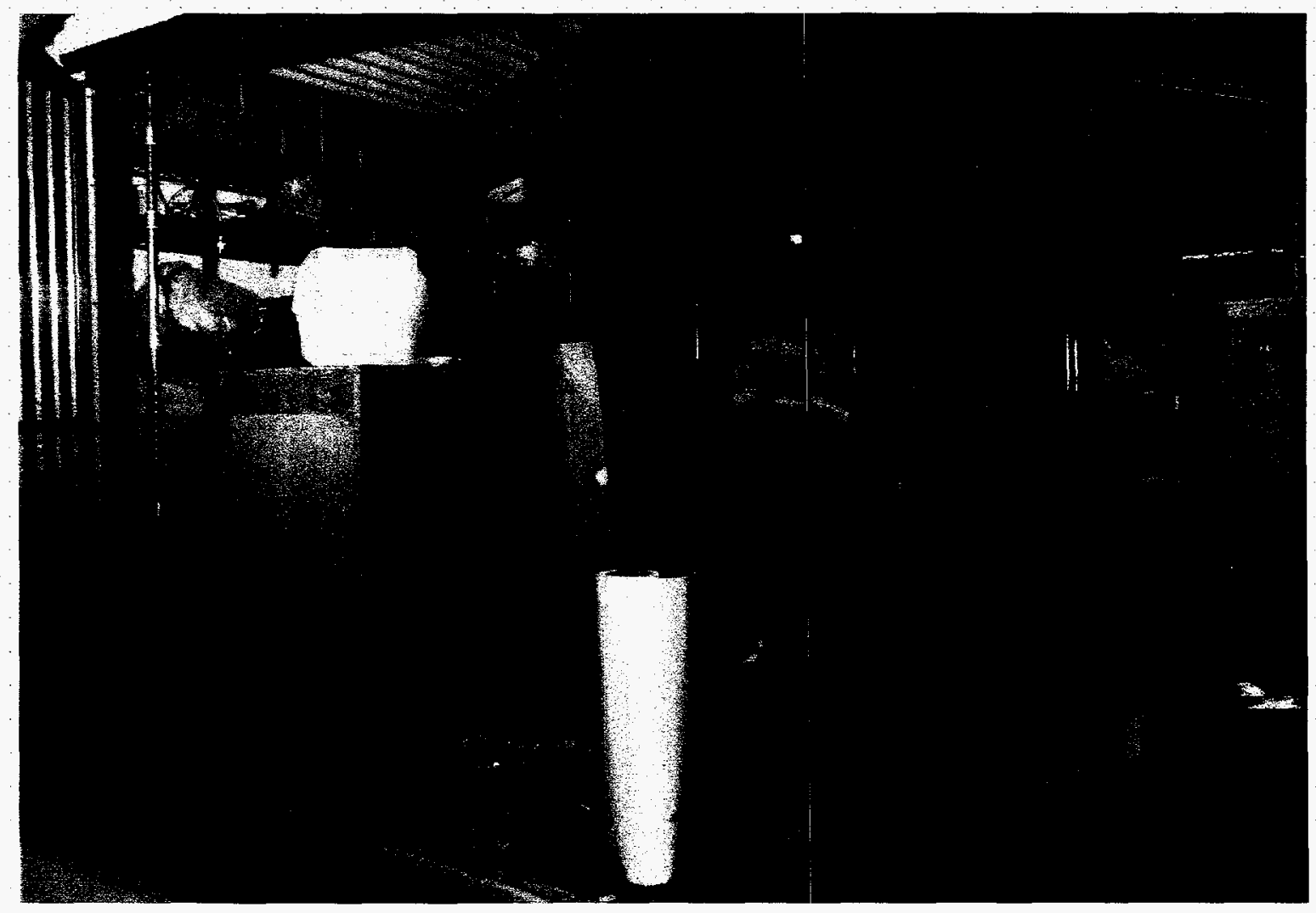

Fig. 2. Bldg. 7025 storage shed: predeactivation. 


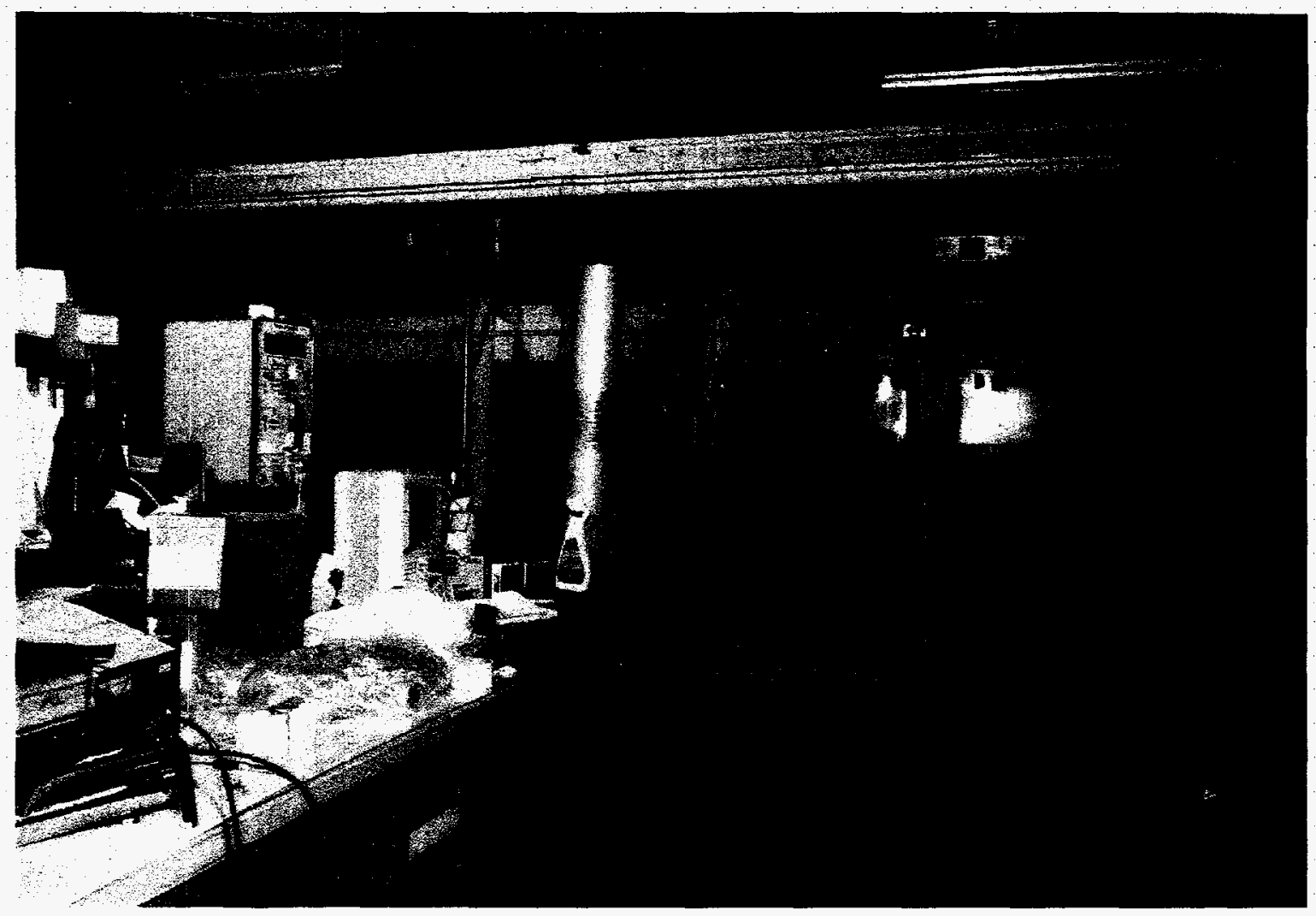

Fig. 3. Inside Bldg. 7025: predeactivation. 




Fig. 4. Inside Bldg. 7025: predeactivation. 
ATTACHMENT 3

BLDG. 7025

DRAWING LIST 

Bldg. 7025 Drawing List

\begin{tabular}{lcl}
\hline Document Number & Revision & \\
\hline A3A-21214-B001 & $z$ & \multicolumn{1}{c}{ Title } \\
C3E-21214-A001 & 002 & $\begin{array}{l}\text { Tritium Target Facility Roof Maintenance } \\
\text { Plan }\end{array}$ \\
E21214ED-001-D & & $\begin{array}{l}\text { Tritium Target Fabrication Bldg. Electrical } \\
\text { Plot Plan }\end{array}$ \\
E21214ED-002-D & & Elec. Power Light Fire Alarm \\
E3E-21214-D003 & B & 7025 Stack Mon-Power Plan P \\
H21214EG-001-D & 002 & Tritium Target Fabrication Bldg. Air \\
H21214EG-002-D & & Handling Sects \\
& & Cooling Equip A-H system Plan Sect Det \\
H3E-21214-G004 & & Notes \\
P21214EC-001-D & & EMS Stack Air Samp Conn P \\
& & Tritium Target Fabrication 185 Gal SST \\
P21214EC-002-D & 001 & Waste Tank \\
& & Tritium Target Fabrication Bldg. PLBG Serv \\
P21214EC-003-D & & Piping Det \\
S21214EB-001-D & & Plot Plan \\
S211402EB-001-D & & Tritium Target Fabrication Bldg. Plan ELS \\
& & Sects \& Dets \\
& & Tritium Target Fabrication Bldg. - Plan \\
& & Elevations, Sections - \& Details \\
\hline
\end{tabular}



ATTACHMENT 4

POSTDEACTIVATION FACILITY PHOTOGRAPHS 



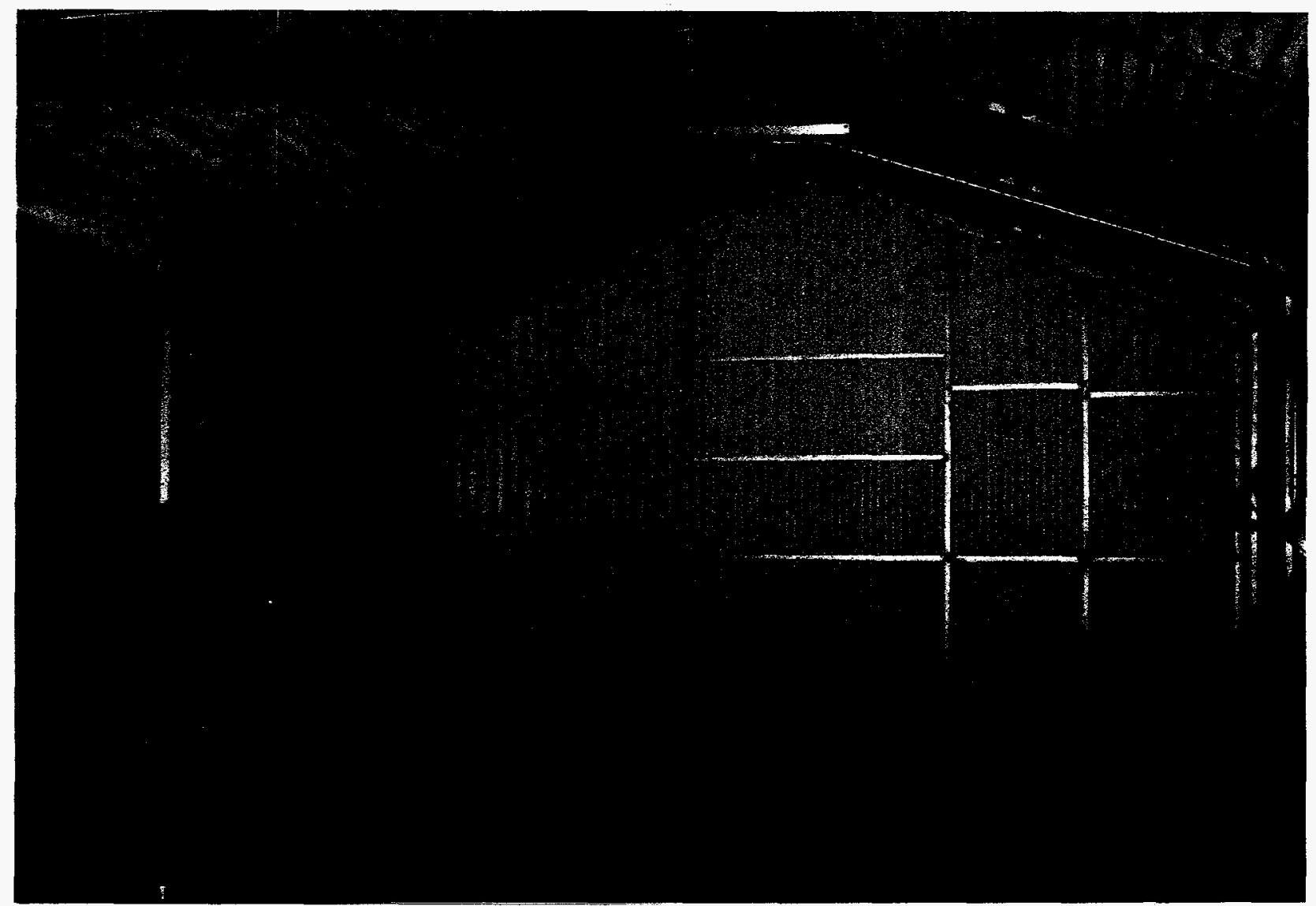

Fig. 1. Storage shed: postdeactivation. 




Fig. 2. Bldg. 7025: postdeactivation. 


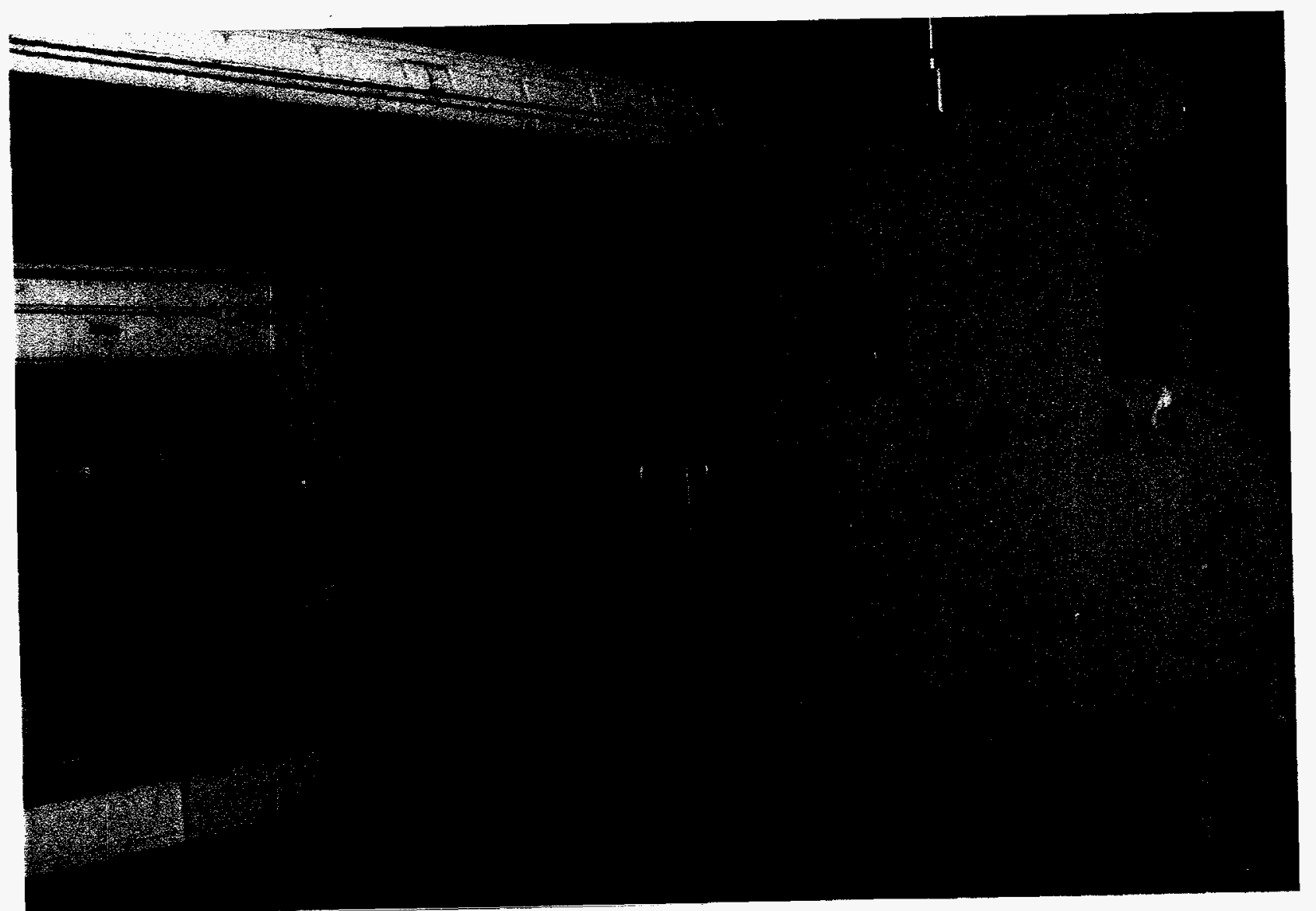

Fig. 3. Bldg. 7025: postdeactivation. 



\section{ATTACHMENT 5}

BLDG. 7025

\section{RADIOLOGICAL SURVEY DATA}





\section{ORNL Radiological Survey Data}

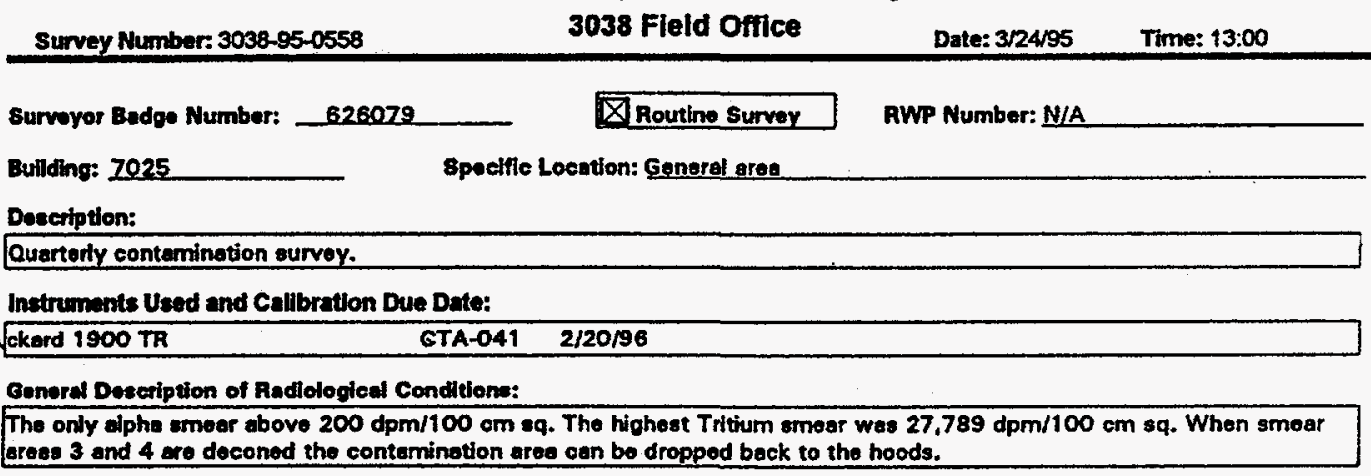

Divielen or Croup Needling the Survor: CT

Personhours spent on the surver: 5

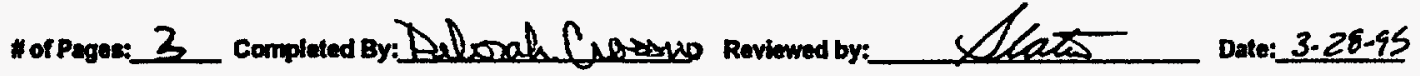

\begin{tabular}{|c|c|c|c|c|c|c|c|c|c|c|c|}
\hline \multicolumn{12}{|c|}{ Smear Results (dpm/100 $\mathrm{cm}^{2}$ unless noted) } \\
\hline $\begin{array}{l}\text { Sumetr } \\
\text { sumber }\end{array}$ & $\boldsymbol{\alpha}$ & $\boldsymbol{\beta}$ & Locention & $\begin{array}{c}\text { Smoat } \\
\text { Number }\end{array}$ & $\boldsymbol{\alpha}$ & $\boldsymbol{\beta}$ & Locatiten & $\begin{array}{c}\text { Smear } \\
\text { mumber }\end{array}$ & $\alpha$ & $\boldsymbol{\beta}$ & Location \\
\hline 1 & $<20$ & $<1000$ & 500 & 2 & $<20$ & $<1000^{\circ}$ & 500 & 3 & $<20$ & 27.789 & 500 \\
\hline 4 & $<20$ & 9,758 & 5000 & 8 & $<2$ & $<1000$ & 300 mins & 6 & $<20$ & $<1000$ & 300 map \\
\hline 7 & 420 & $<1000$ & 500 & 8 & $<20$ & $<1000$ & 800 nim & 9 & $<20$ & $<1000$ & Sin mepp \\
\hline 10 & $<2$ & $<1000$ & 500 & 11 & 20 & $<1000$ & $50 \times 10$ & 12 & $<20$ & $<1000$ & 500 \\
\hline 13 & 20 & $<1000$ & $\sin \operatorname{mos}$ & 14 & $<20$ & $<1000$ & 8000 & 15 & $<20$ & $<1000$ & 500 mose \\
\hline 16 & 20 & $<1000$ & 300100 & 17 & $<20$ & $<1000$ & 8000 & 18 & $<20$ & $<1000$ & $\operatorname{sen} m$ \\
\hline 19 & $\mathbf{2 0}$ & $<1000$ & $\sin \min _{0}$ & 20 & $<20$ & 2,222 & Sen & 21 & $<20$ & 2,024 & Sen \\
\hline 22 & $<20$ & 1,698 & $\lim$ & 23 & 220 & $<1000^{+}$ & Sin ming & 24 & $<20$ & 1,121 & Soun nom \\
\hline 28. & $<20$ & 1,479 & $39 \ln$ & 26 & 20 & $<1000$ & $500 \quad m=0$ & 27 & $<20$ & $<1000$ & 500 niop \\
\hline 28 & $<20$ & $<1000$ & 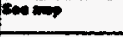 & 20 & $<20$ & $<1000$ & Bom & 30 & $<20$ & $<1000$ & 500 \\
\hline 31 & $<20$ & $<1000$ & 3000 & 32 & 20 & $<1000$ & $\sin \mathrm{n}$ & 33 & $<20$ & $<1000$ & 500 \\
\hline 34 & 20 & $<1000$ & 2000 & 36. & $<20$ & $<1000$ & 3000 & 38 & $<20$ & $<1000$ & Som men \\
\hline 37 & $<20$ & $<1000$ & Seen & 38 & $<20$ & $<1000$ & $500 \times$ & 39 & 101 & $<1000$ & Set map \\
\hline
\end{tabular}









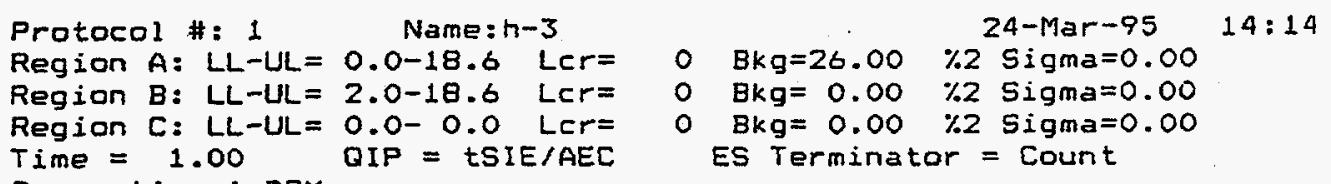

\begin{tabular}{|c|c|c|c|c|c|c|c|c|c|}
\hline S\# & TIME & CPMA & DPM1 & $A: 25 \%$ & CPMB & SIS & tSIE & LUM & FLAG \\
\hline 1 & 1.00 & 183.00 & 444.92 & 15.46 & 200.00 & 9.072 & 375. & 11 & \\
\hline 2 & 1.00 & 97.00 & 257.58 & 29.94 & 122.00 & 8.898 & 333. & 47 & \\
\hline 3 & 1.00 & 11565.0 & 27789.0 & 1.87 & 11083.0 & B. 955 & 382. & 1 & \\
\hline 4 & 1.00 & 3863.00 & 9758.58 & 3.23 & 3710.00 & 8.688 & 356. & 1 & \\
\hline 5 & 1.00 & 75.00 & 184.23 & 21.60 & 94.00 & 8.883 & 370. & 8 & \\
\hline 6 & 1.00 & 92.00 & 226.63 & 20.62 & 115.00 & 9.387 & 368. & 11 & \\
\hline 7 & 1.00 & 255.00 & 641.02 & 12.55 & 265.00 & 8.105 & 358. & 5 & \\
\hline 8 & 1.00 & 58.00 & 140.11 & 23.33 & 82.00 & 9.821 & 379. & 6 & \\
\hline 9 & 1.00 & 72.00 & 175.63 & 21.60 & 95.00 & 9.597 & 373. & 6 & \\
\hline 10 & 1.00 & 33.00 & 84.57 & 32.69 & 61.00 & 10.525 & 349. & 23 & \\
\hline 11 & 1.00 & 269.00 & 677.75 & 12.52 & 280.00 & 8.767 & 357. & $\theta$ & \\
\hline 12 & 1.00 & 22.00 & 57.12 & 35.36 & 48.00 & 9.764 & 343 . & 20 & \\
\hline 13 & 1.00 & 52.00 & 129.93 & 25.64 & 77.00 & 9.482 & 361. & 12 & \\
\hline 14 & 1.00 & 157.00 & 429.78 & 15.26 & 177.00 & 8.823 & 321. & 3 & \\
\hline 15 & 1.00 & 54.00 & 140.07 & 23.18 & 73.00 & 8.466 & 344. & 4 & \\
\hline 16 & 1.00 & 266.00 & 657.95 & 12.02 & 284.00 & 9.168 & 366. & 3 & \\
\hline 17 & 1.00 & 58.00 & 145.00 & 24.05 & 84.00 & 9.838 & 361. & 9 & \\
\hline 18 & 1.00 & 12.00 & 28.95 & 34.91 & 36.00 & 11.953 & 379. & 8 & \\
\hline 19 & 1.00 & 96.00 & 235.59 & 18.83 & 115.00 & 9.444 & 370. & 4 & \\
\hline 20 & 1.00 & 878.00 & 2222.23 & 6.70 & 862.00 & 8.739 & 355 . & 1 & \\
\hline 21 & 1.00 & 890.00 & 2024.52 & 6.69 & 865.00 & 8.770 & 417. & 1 & \\
\hline 22 & 1.00 & 703.00 & 1698.84 & 7.52 & 684.00 & 7.732 & 378. & 1 & \\
\hline 23 & 1.00 & 87.00 & 233.82 & 19.79 & 109.00 & 9.587 & 328. & 5 & \\
\hline 24 & 1.00 & 452.00 & 1121.45 & 9.52 & 460.00 & 9.284 & 365. & 4 & \\
\hline 25 & 1.00 & 598.00 & 1479.95 & 8.12 & 599.00 & 8.983 & 366. & 1 & \\
\hline 26 & 1.00 & 76.00 & 185.58 & 20.75 & 84.00 & 9.095 & 373. & 4 & \\
\hline 27 & 1.00 & 60.00 & 144.94 & 21.57 & 83.00 & 10.712 & 379. & 0 & \\
\hline 28 & 1.00 & 22.00 & 55.15 & 31.73 & 43.00 & 9.262 & 360. & 10 & \\
\hline 29 & 1.00 & 8.00 & 21.57 & 42.42 & 34.00 & 10.318 & 327 & 23 & \\
\hline 30 & 1.00 & 73.00 & 197.38 & 21.09 & 95.00 & B. 220 & 326. & 5 & \\
\hline 31 & 1.00 & 16.00 & 42.76 & 32.99 & 41.00 & 10.824 & 331. & 7 & \\
\hline 32 & 1.00 & 14.00 & 41.17 & 37.42 & 41.00 & B. 809 & 294 . & 18 & \\
\hline 33 & 1.00 & 25.00 & 64.30 & 33.51 & 51.00 & 11.203 & 347. & 18 & \\
\hline 34 & 1.00 & 24.00 & 62.49 & 34.87 & 50.00 & 日.843 & 342 . & 21 & \\
\hline 35 & 1.00 & 45.00 & 134.97 & 24.07 & 69.00 & 9.028 & 288. & 2 & \\
\hline 36 & 1.00 & 22.00 & 54.19 & 31.18 & 47.00 & 10.023 & 368 . & 6 & \\
\hline 37 & 1.00 & 36.00 & 84.55 & 28.12 & 59.00 & 10.089 & 396. & 9 & \\
\hline 38 & 1.00 & 79.00 & 204.16 & 19.70 & 102.00 & 10.251 & 345. & 1 & \\
\hline 39 & 1.00 & 276.00 & 719.34 & 11.74 & 287,00 & 8.960 & 341. & 2 & \\
\hline $\begin{array}{l}40 \\
41\end{array}$ & $\begin{array}{l}1.00 \\
1.00\end{array}$ & $\begin{array}{r}120894 . \\
0.00\end{array}$ & $\begin{array}{r}183433 \\
0.00\end{array}$ & $\begin{array}{r}0.58 \\
48.99\end{array}$ & $\begin{array}{r}109318 . \\
19.00\end{array}$ & $\begin{array}{l}19.984 \\
21.400\end{array}$ & $\begin{array}{l}7011 \\
1008\end{array}$ & $\begin{array}{r}0 \\
10\end{array}$ & \\
\hline
\end{tabular}

Predeurd 1900TR 


\section{ORNL Radiological Survey Data}

Description:

Disassembly, segregation and packeging of equipment (H-3 system) in and on top of the hoads.

Instruments Used and Calibration Due Date:

Date:

$$
\text { LSC CTB:047 }
$$

The maximum loose contamination at the beginning of the job was 2.9 billion $\mathrm{dpm} / 100 \mathrm{~cm}$ sq bete $(\mathrm{H}-3)$. The general araa loose contamination levels wore $<10,000 \mathrm{dpm} / 100 \mathrm{~cm}$ sq beta $(\mathrm{H}-3)$. Only one contamination survey was done in the high contamination area except for the step off pad, during the job due to time considerations, air supply, cost of saranex suits and the amount of waste that would have been generated by tring to keep the high contamination area levels down. The maximum loose contamination in the high contamination area was $178,112 \mathrm{dpm} / 100 \mathrm{~cm}$ sq beta (H-3) on this survey which is included in this paperwork. The contamination area and step off pads were deconned repeatedly during the job because of its small size and a need to keop this area at lower levels. Smear date prior to deconning is given in the following pages. The highest smear in the high contemination area was $372.028 \mathrm{dpm} / 100 \mathrm{~cm}$ sq bete (H-3) and $42,508 \mathrm{dpm} / 100 \mathrm{~cm}$ sq beta $(H-3)$ in the contemination erea at the end of the job the rest of the results are listed below. The air monitor (set at $50 \mathrm{uCi} /$ meters cubed) never went into high level during the job. No personnel ware conteminated to a biosssay count lovel requiring a recount. The maximum skin contamintion level found after a job was $5.996 \mathrm{dpm} / 100 \mathrm{~cm}$ sq bota $(\mathrm{H}-3)$. The Packard 1900TR liquid scintillation counter was used to count smears.

Division of Group Noeding the Survey: CT CT

Pereon-hours spent on the survey: 136.6



\begin{tabular}{|c|c|c|c|c|c|c|c|c|c|c|c|}
\hline \multicolumn{12}{|c|}{ Smear Results (dpm/100 $\mathrm{cm}^{2}$ unless noted) } \\
\hline $\begin{array}{c}\text { Smear } \\
\text { Numbor } \\
\end{array}$ & $\alpha$ & $\beta$ & Location & $\begin{array}{c}\text { Smear } \\
\text { Number }\end{array}$ & $\alpha$ & $\boldsymbol{\beta}$ & Location & $\begin{array}{c}\text { Smior } \\
\text { Number }\end{array}$ & $\alpha$ & $\beta$ & Location \\
\hline 1 & NC & 11,073 & sean andop & 2 & NC & 7,464 & $\operatorname{sen} \operatorname{man}$ & 3 & NC & 14,593 & $S=0$ \\
\hline 4 & NC & 3,565 & sen ines & 5 & NC & 7,349 & $\operatorname{sen}=0$ & 6 & NC & 23,268 & $\sin m$ \\
\hline 7 & NC & 25,180 & sete mase & 8 & NC & 15,446 & $\operatorname{sen} \min$ & 9 & NC & 25,079 & $500 \operatorname{mos}$ \\
\hline 10) & NC) & 31,858 & Sen med & 11 & NC & 204,276 & Sentase & 12 & NC & 372,028 & sen mans \\
\hline 13 & NC & 66,624 & seon aneos & 14 & NC & 61,325 & $\operatorname{sen} \operatorname{mos}$ & 15 & NC & 48,266 & $500 \mathrm{mes}$ \\
\hline 16 & NC & 20.447 & 500 man & 17 & NC & 24,299 & Sen & 18 & NC & 266,104 & $500 \operatorname{mos}$ \\
\hline 19 & NC & 77,183 & $\operatorname{sen} m \infty 0$ & 20 & $\mathrm{NC}$ & 646,327 & $\operatorname{sen} m$ & 21 & NC & 172,936 & $\operatorname{sen} \operatorname{mas}$ \\
\hline 22 & NC & 70,721 & Sep nop & 23 & $\mathrm{NC}$ & 44,021 & $500 \min$ & 24 & NC & 85,36 & Sod mase \\
\hline 25 & NC) & 20,224 & $\operatorname{sen} \operatorname{man}$ & 26) & NC & 331,599 & $500 \min$ & 27 & NC) & 42.508 & $s \rightarrow \infty \operatorname{map}$ \\
\hline 28 & NC & 486 & See mes & 29 & NC & 375 & Sin map & 30 & $\mathrm{NC}$ & 525 & $\operatorname{sen} \max$ \\
\hline 31 & NC & 921 & $500 \operatorname{mos}$ & 32 & NC & 1,520 & 500 & 33 & $\mathrm{NC}$ & 1.862 &  \\
\hline 34 & NCI & 925 & 500 mense & 35 & NC & 790 & 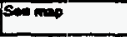 & & & & \\
\hline
\end{tabular}


$3038-96-1657$

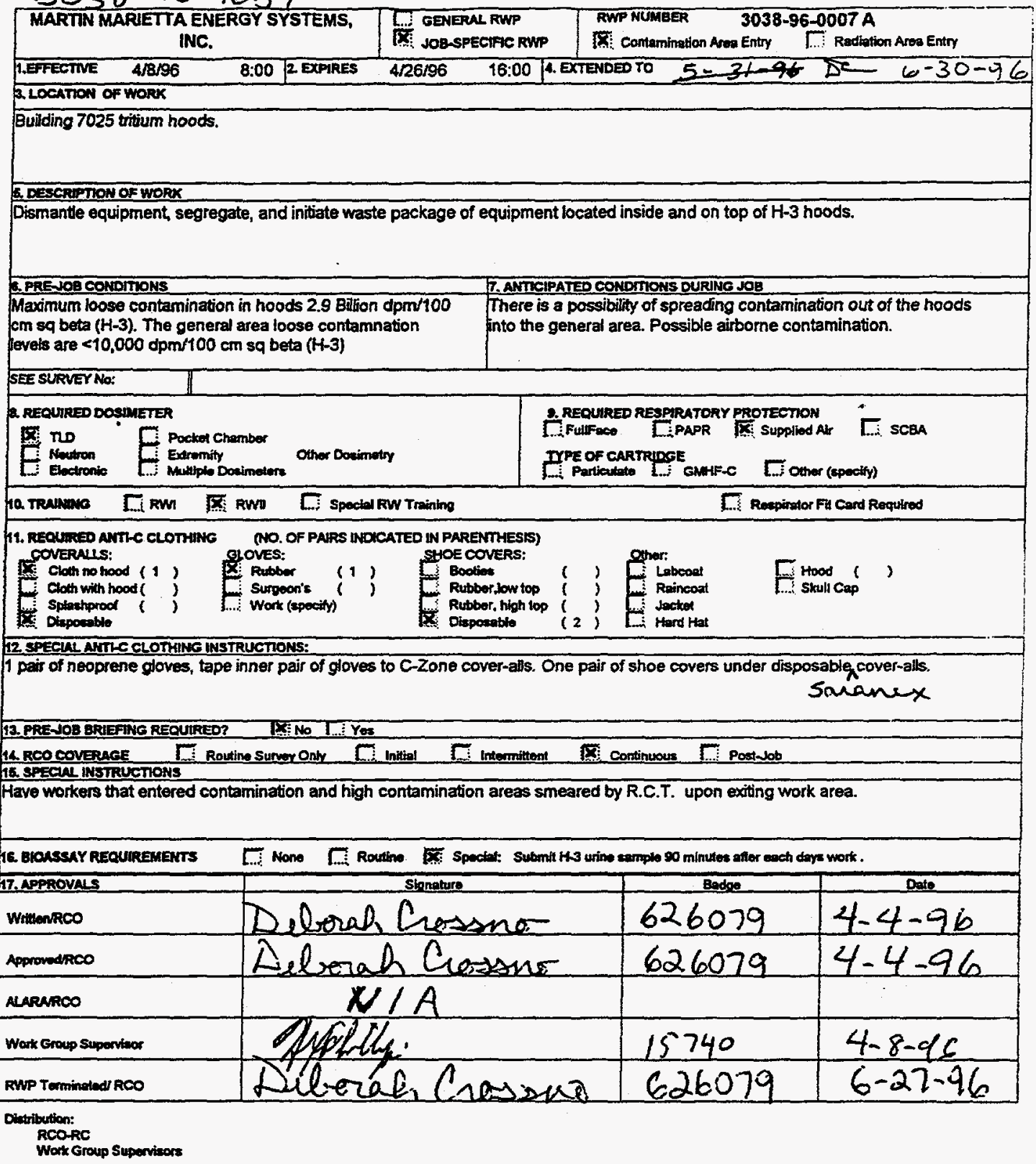




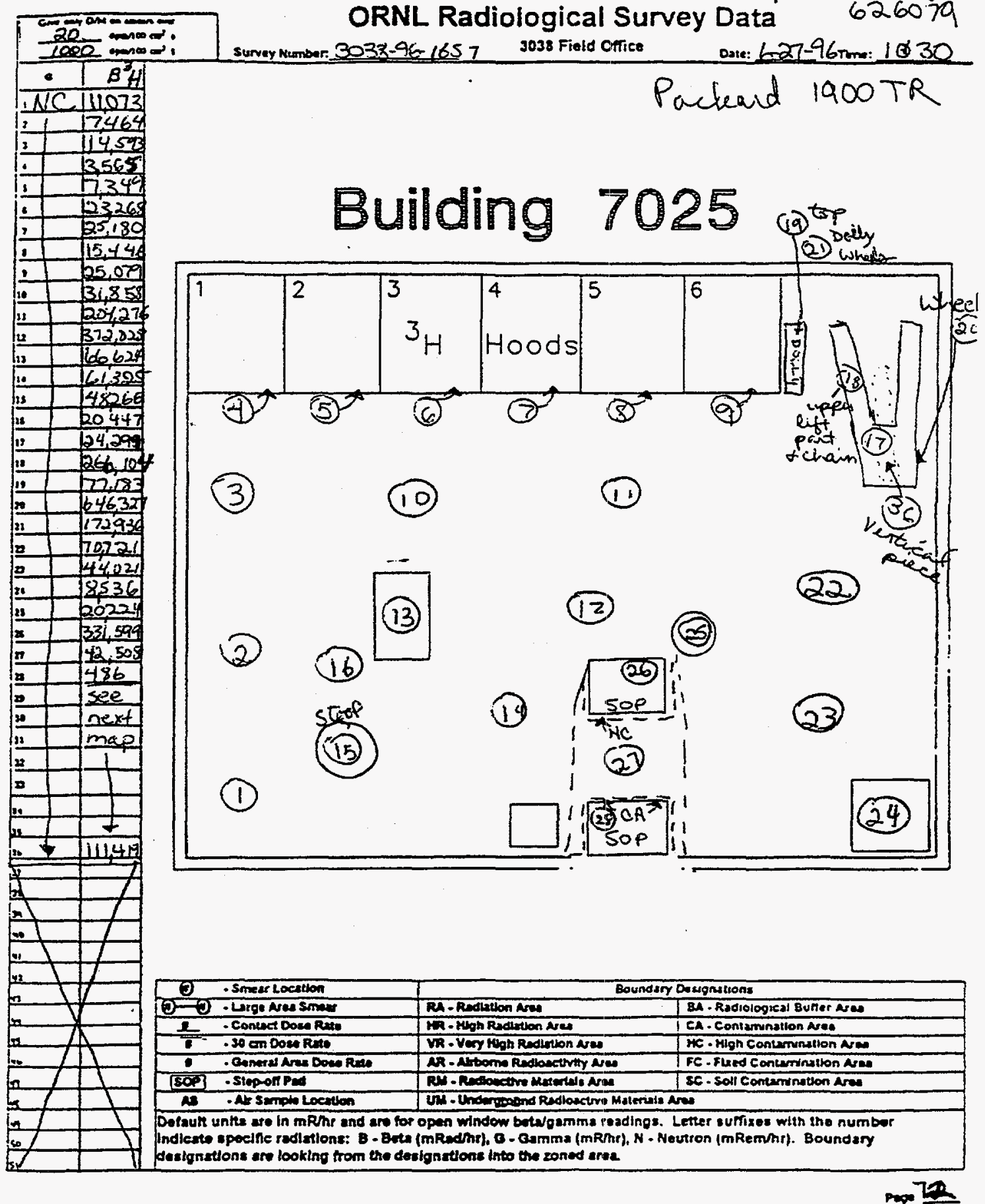

Niborak cirons ORNL Radiological Survey Data 626079 


\section{Deboak Crossno 626079} ORNL Radiological Survey Data Survey Number: $203896-1657$

3038 Field Office axta 6-27-96 thme: 1030

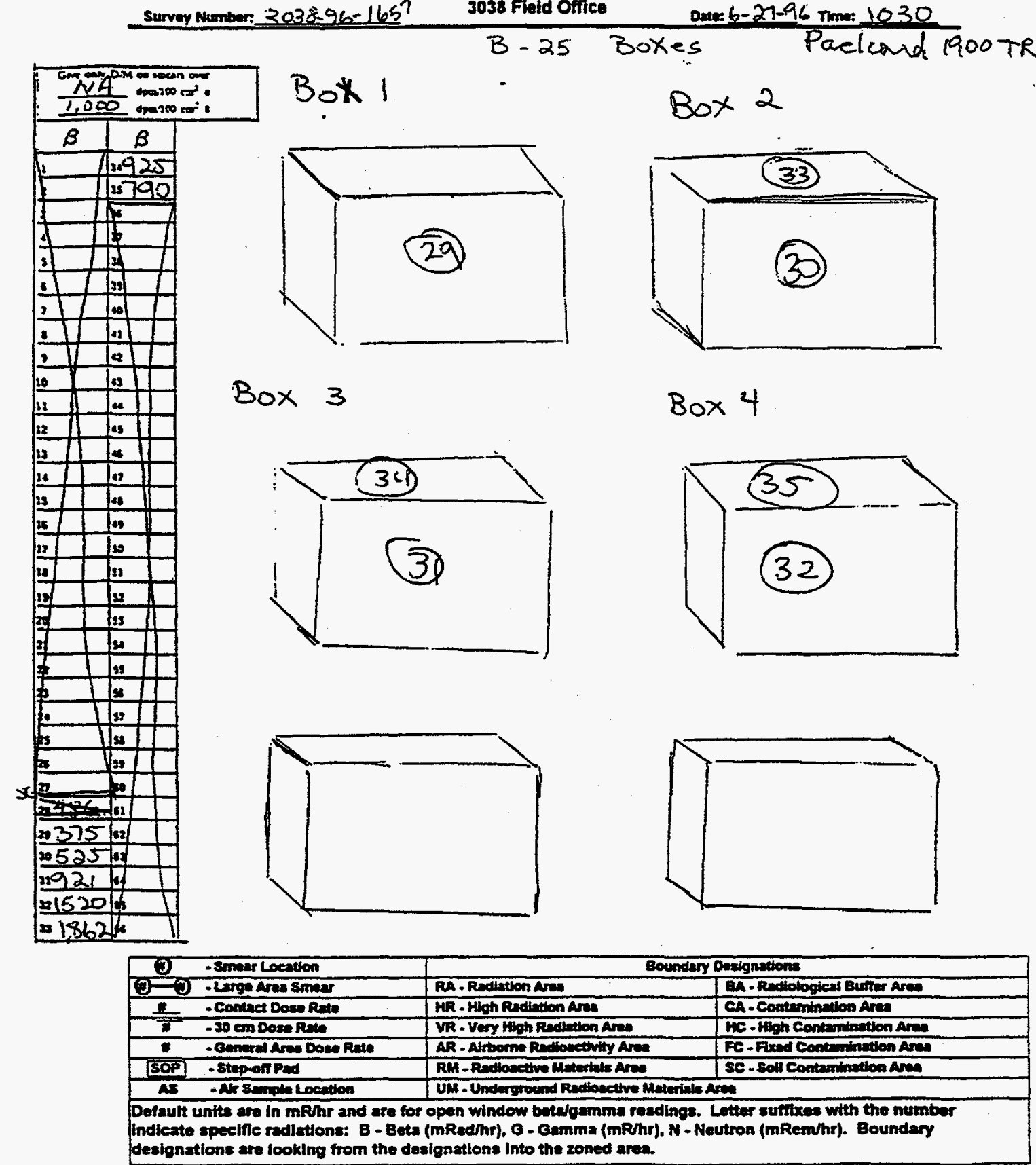




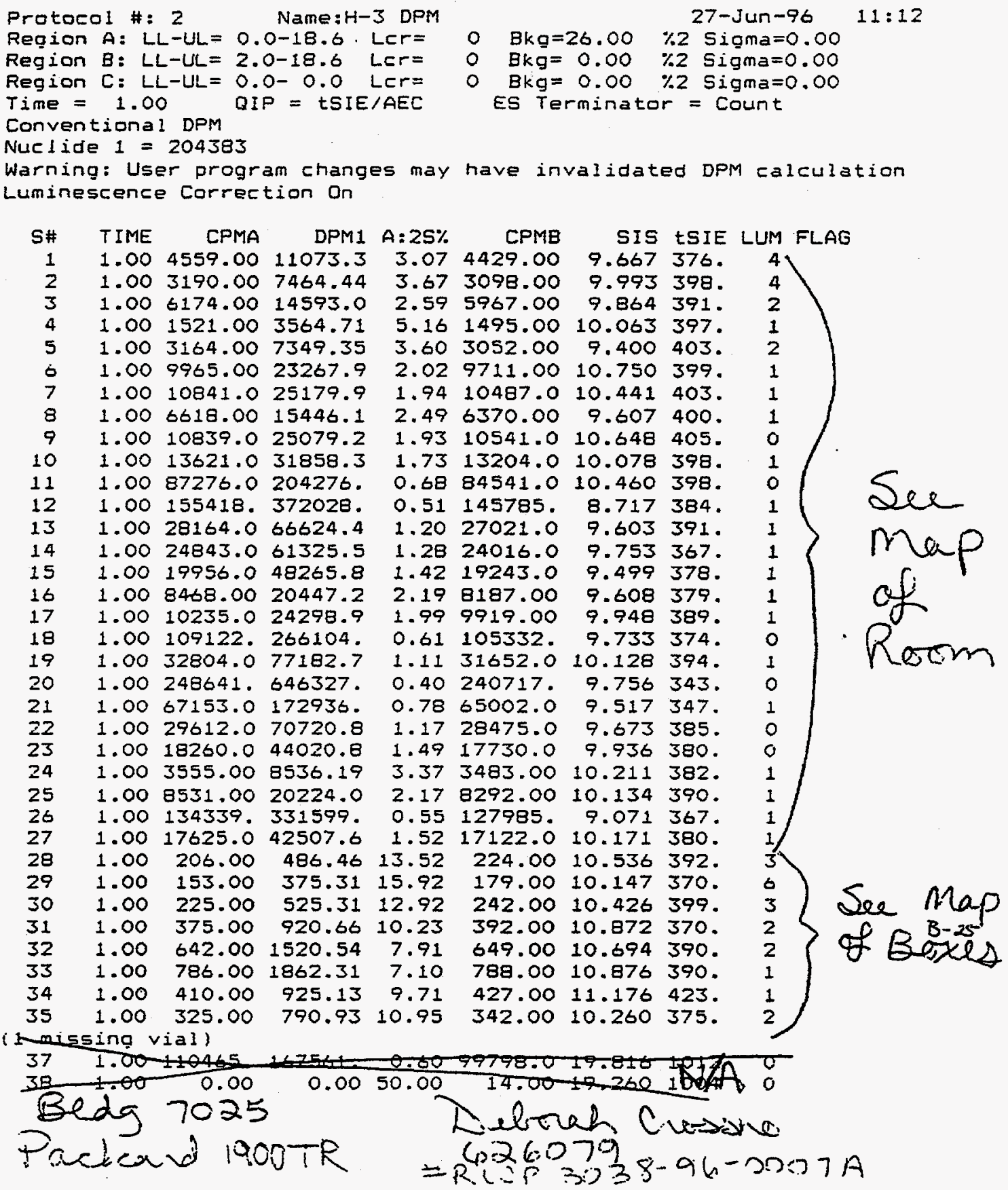


5-11
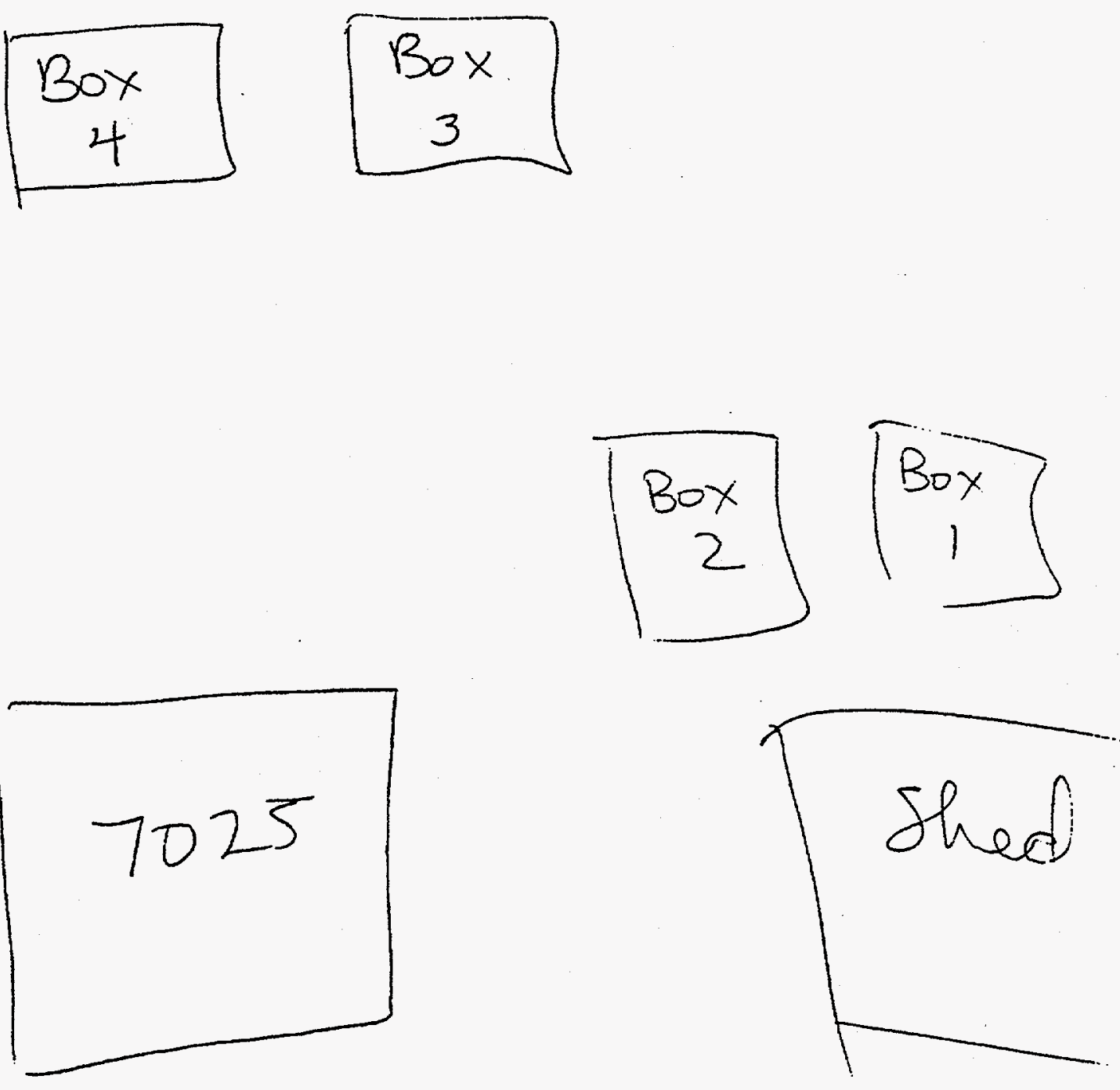
5-12

Protocol \#: $3 \quad$ Name:H-3 DPM Region A: LL-UL $=0.0-18.6$. Le Region $C: L L-U L=0.0-0.0$ Le Time $=1.00$ QIP = tSIE/AEC Conventional DPM Nuclide $1=204383$ Warning: User program changes may have invalidated DPM calculation
Luminescence Correction On
$B k g=26.00$

$B k g=0.00$

$B k g=0.00$

ES Terminator
27-Jun-96

Sigma =0.00

$r=$ Count
Sigma =0.00

$12: 19$

ind 36

Deborah Cassino

se map

626079 


\section{ORNL Radiological Survey Data}

Description:

Deconning inside of building and outside of b-25 boxes as needed.

Instruments Used and Callbration Due Date:

$$
\text { LSC CTB:047 }
$$

$3 / 1 / 97$

CTA-OA1

$3 / 1 / 97$

General Description of Radiological Conditions:

Inside building 7025 the highest smear was $446.518 \mathrm{dpm} / 100 \mathrm{~cm}$ sq beta $(\bar{H}-3)$ on $7 / 17 / 96$. The higher smears were on and near the H-3 hoods along the south wall. After deconning repeatedly the majority of the room smeared $<1,000$ $\mathrm{dpm} / 100 \mathrm{~cm}$ sq beta on 10/17/96. The area around the hood was roped off as a contamination area and inside this area a high contamination area was placed right at the hoods. The B-25 boxes were smeared after all of them were filled. Four of the boxes had to be roped off as a contamination area the highest the boxes smeared during this time was 672.939 $\mathrm{dpm} / 100 \mathrm{~cm}$ sq beta from around the lid on the box with highest contaminated waste. The boxes were deconned but because of the level of contamination and the heat they would repeatedly show up contaminated due to the $H-3$ off gassing around the gasket on the lid. When it rained the levels would go down. but at no time did the ground around the boxes smear $>1,000 \mathrm{dpm} / 100 \mathrm{~cm}$ sq beta. The $\mathrm{B}-25$ boxes were deconned and smeared $<1,000 \mathrm{dpm} / 100 \mathrm{~cm} s q \mathrm{beta}$ on 12/20/96, they were picked up and removed from the area shortly after that. The Packard 3900 TR liquid scintillation counter was used to count the $\mathrm{H}-3$ smears. All personnel smeared $1,000 \mathrm{dpm} / 100 \mathrm{~cm}$ sq beta, smear data and sign in sheets contained within this write-up. No airborne contamination was detected during the job.

Division or Group Needing the Survey: 
Deborah lrossmo




Deborah Vresono

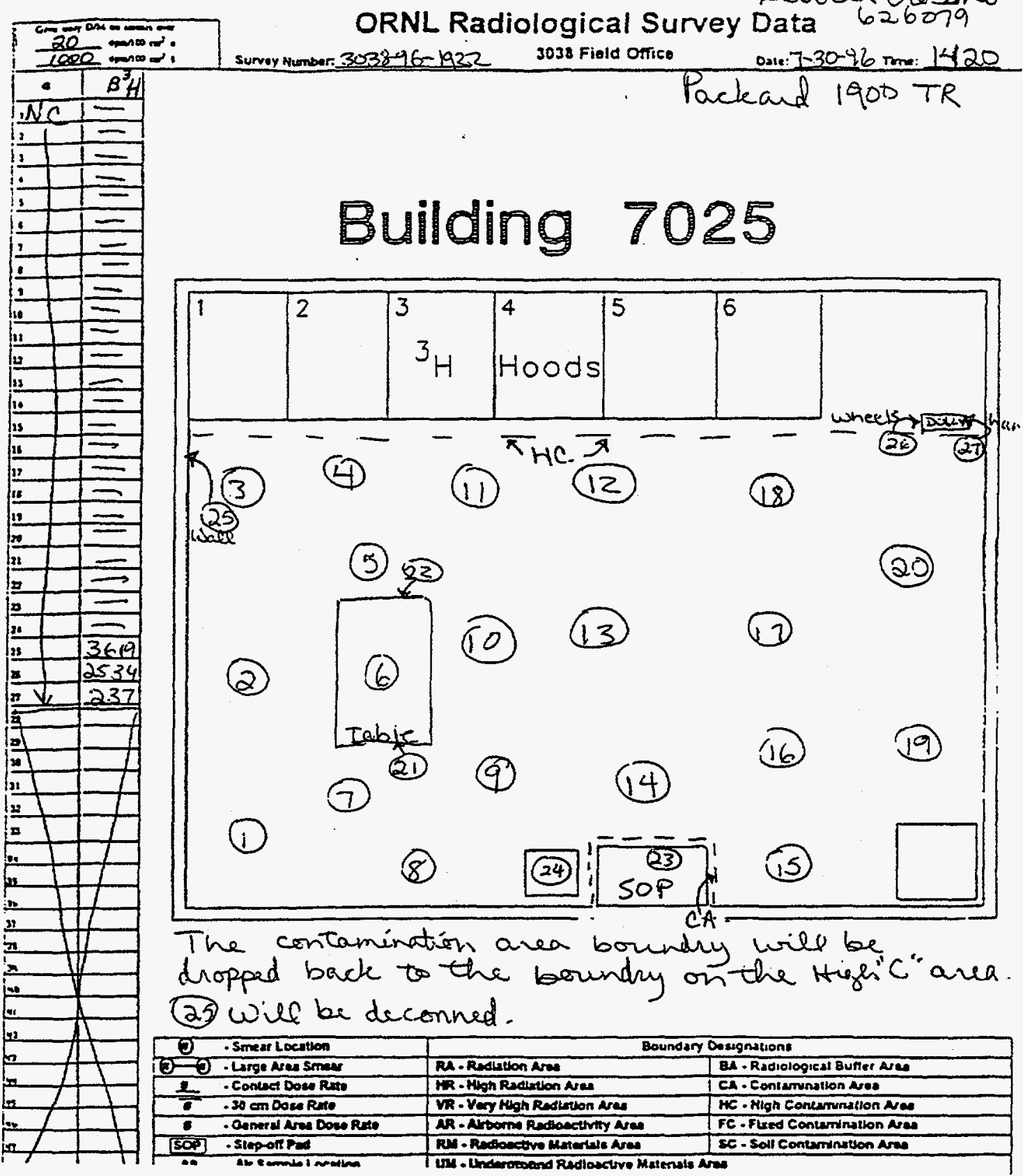




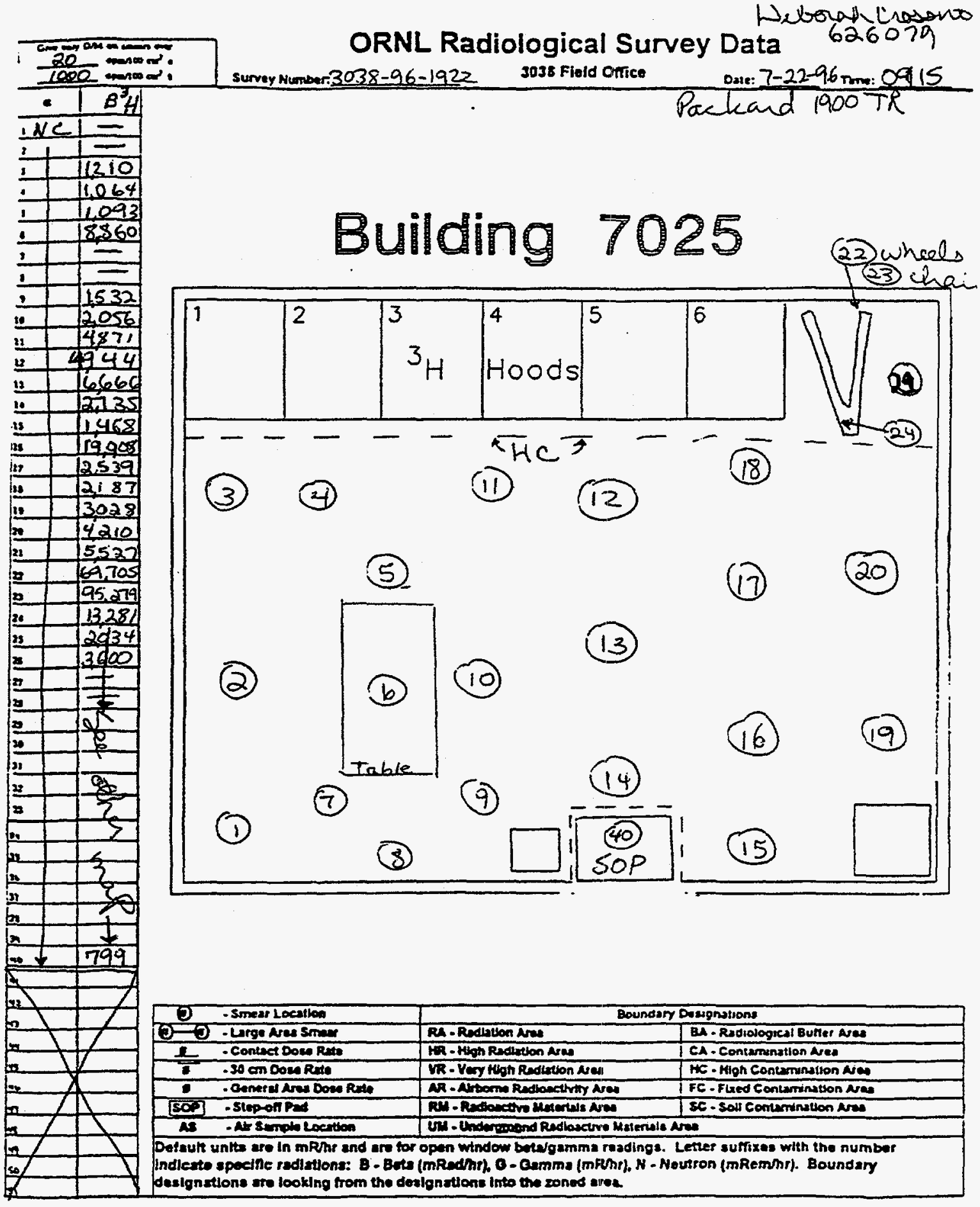

Weborak Liosono Data Dare: $7-22-96$ nme: 0915

27 


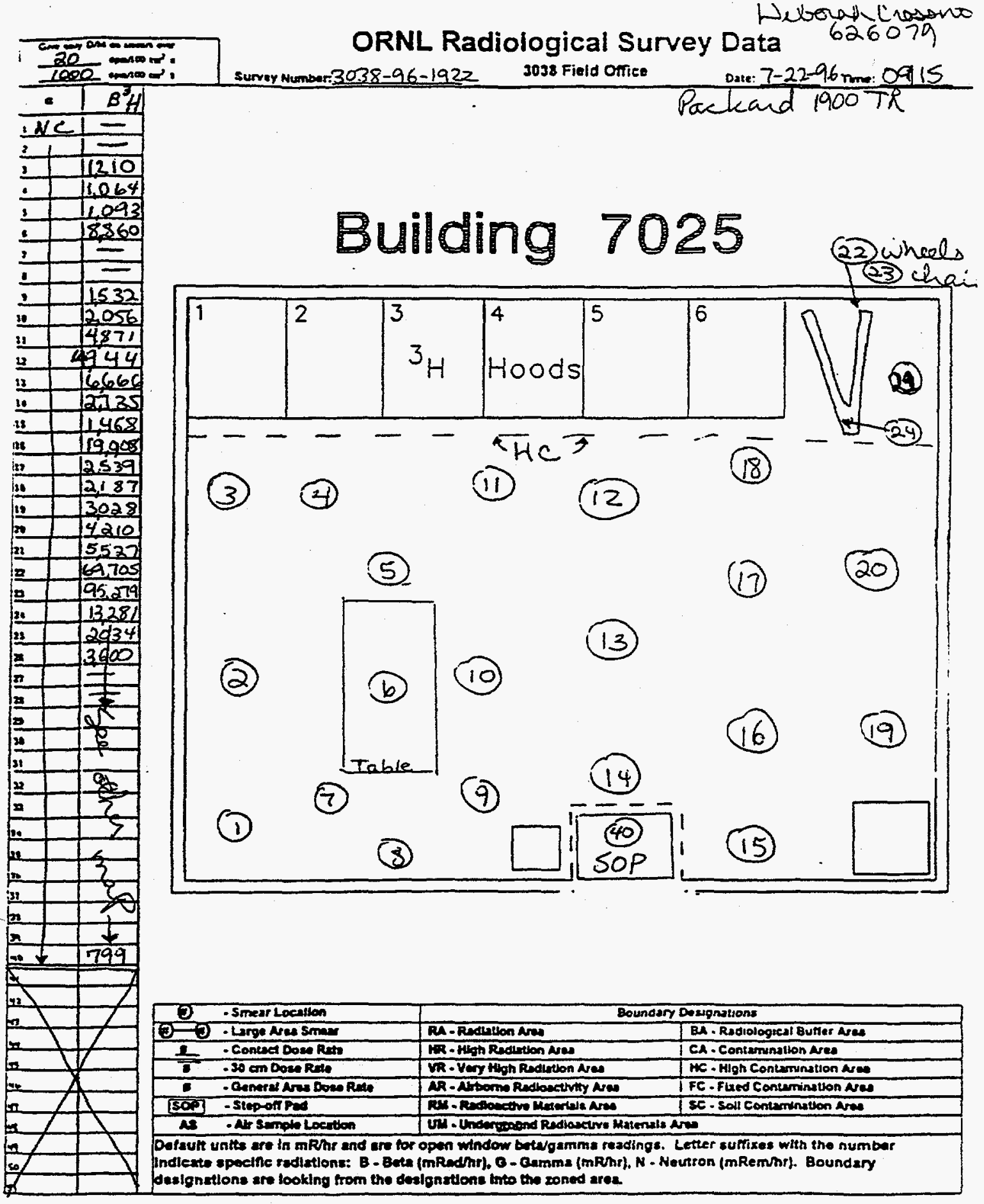

Heboral crosono ORNL Radiological Survey Data 626079

Building 7025 (22) wheels 


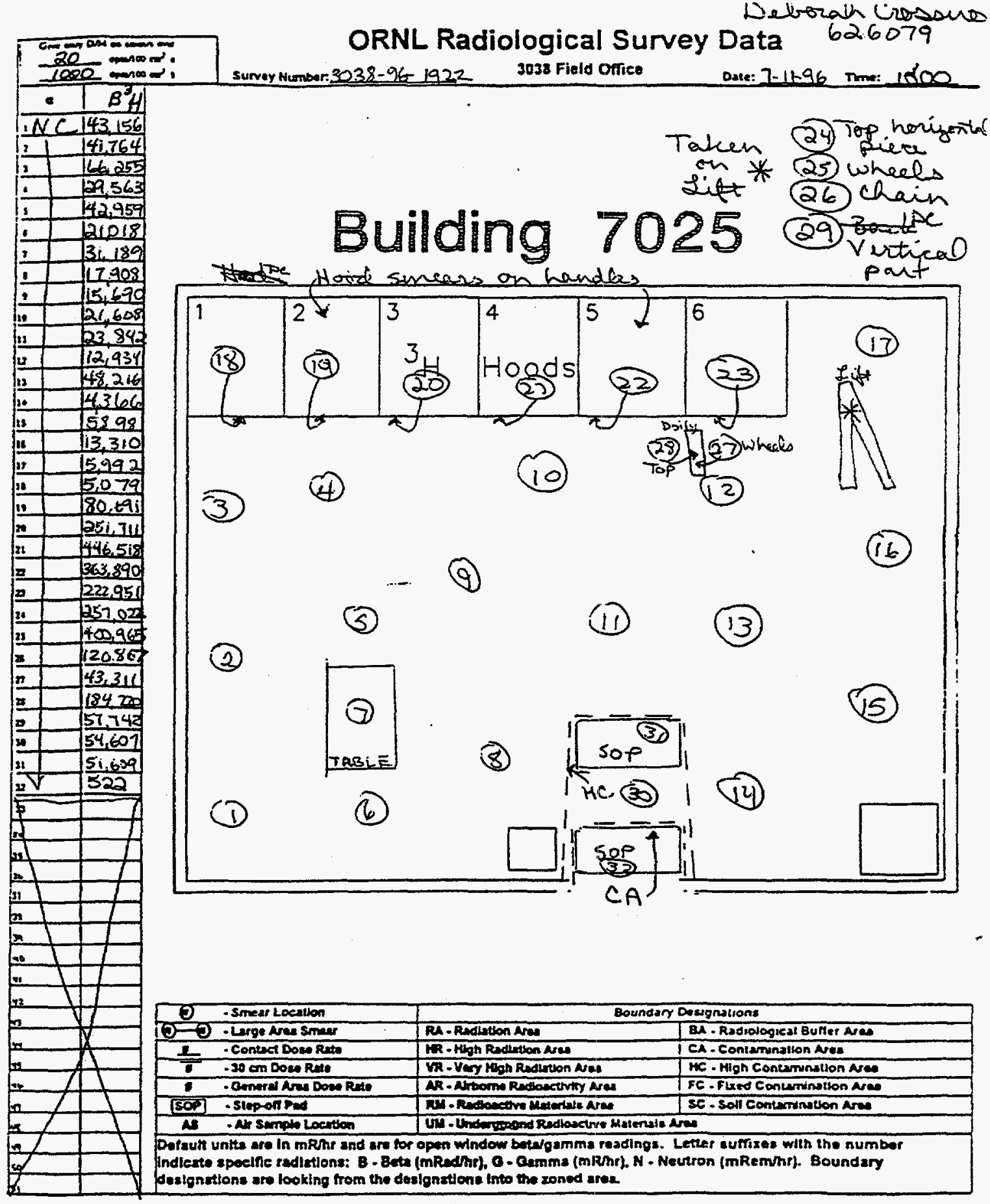




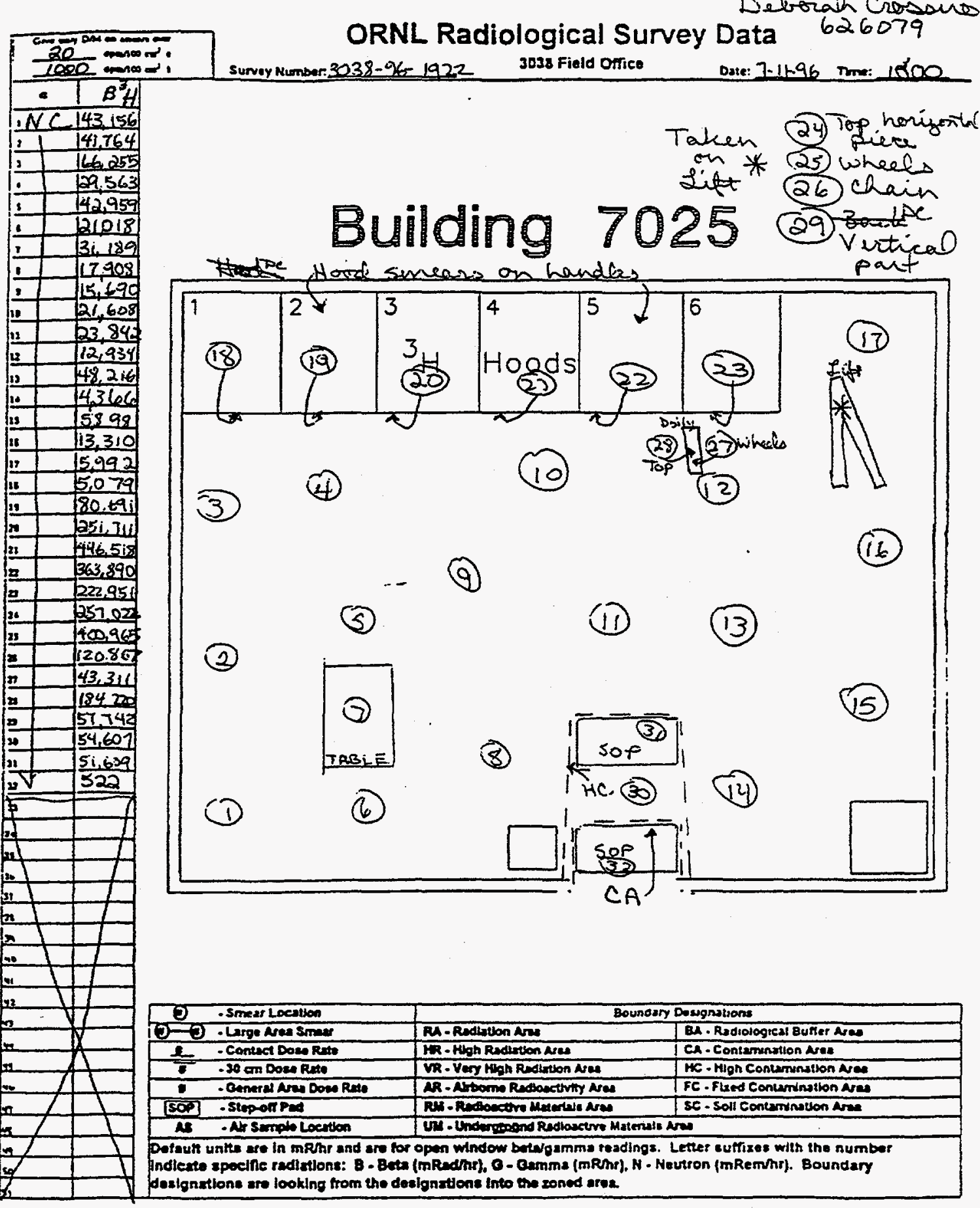




\section{ORNL Radiological Survey Data}

Surveyor Badge Number: $\quad 626079$

DRoutine Survey

RWP Number: 3038-97-0002A

Building: 7025

Specific Location: General area

Description:

Quarterfy contamination survey.

Instruments Used and Caltbration Due Date:

$$
\text { CTA-04i 3/1/98 }
$$

General Description of Radiological Conditions:

The highest smear was 2.758.520.000 dpm $/ 100 \mathrm{~cm}$ sq beta $(\bar{H}-3)$ from inside hood no.4. The highes: smear from outside the hoods was $99.571 \mathrm{dpm} / 100 \mathrm{~cm}$ sq beta. All smears were $<20 \mathrm{dpm} / 100 \mathrm{~cm}$ sq alpha. Two of the hood smears had to be diluted to get the $\mathrm{dpm}$ because they were so high the counter couldn't count them. The Packard 1900 TR liquid scintillation counter was used to count the smears. The atpha smears were taken on defensap smears and counted with a portable instrument to eliminate the possibility of contaminating the smear counter.

Division or Group Needing the Survey:

$\mathrm{CT}$

Person-hours spent on the survey:

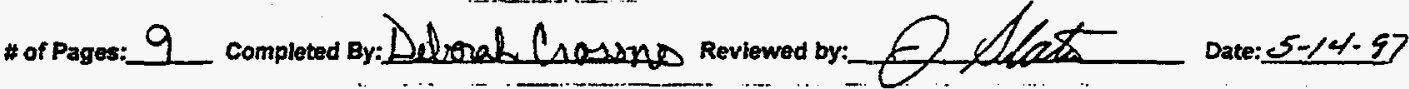

Smear Results (dpm/100 $\mathrm{cm}^{2}$ unless noted)

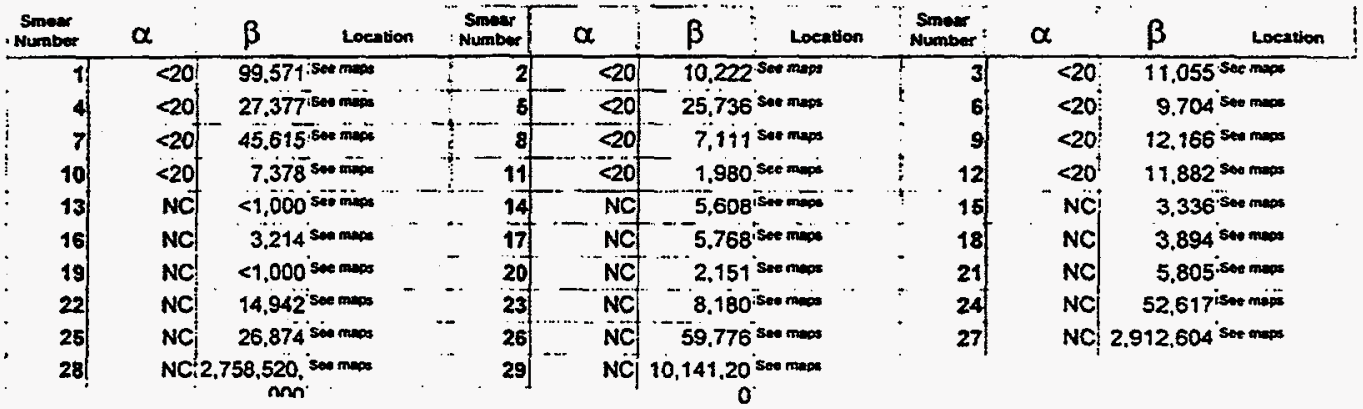


ORNL Radiological Survey Data
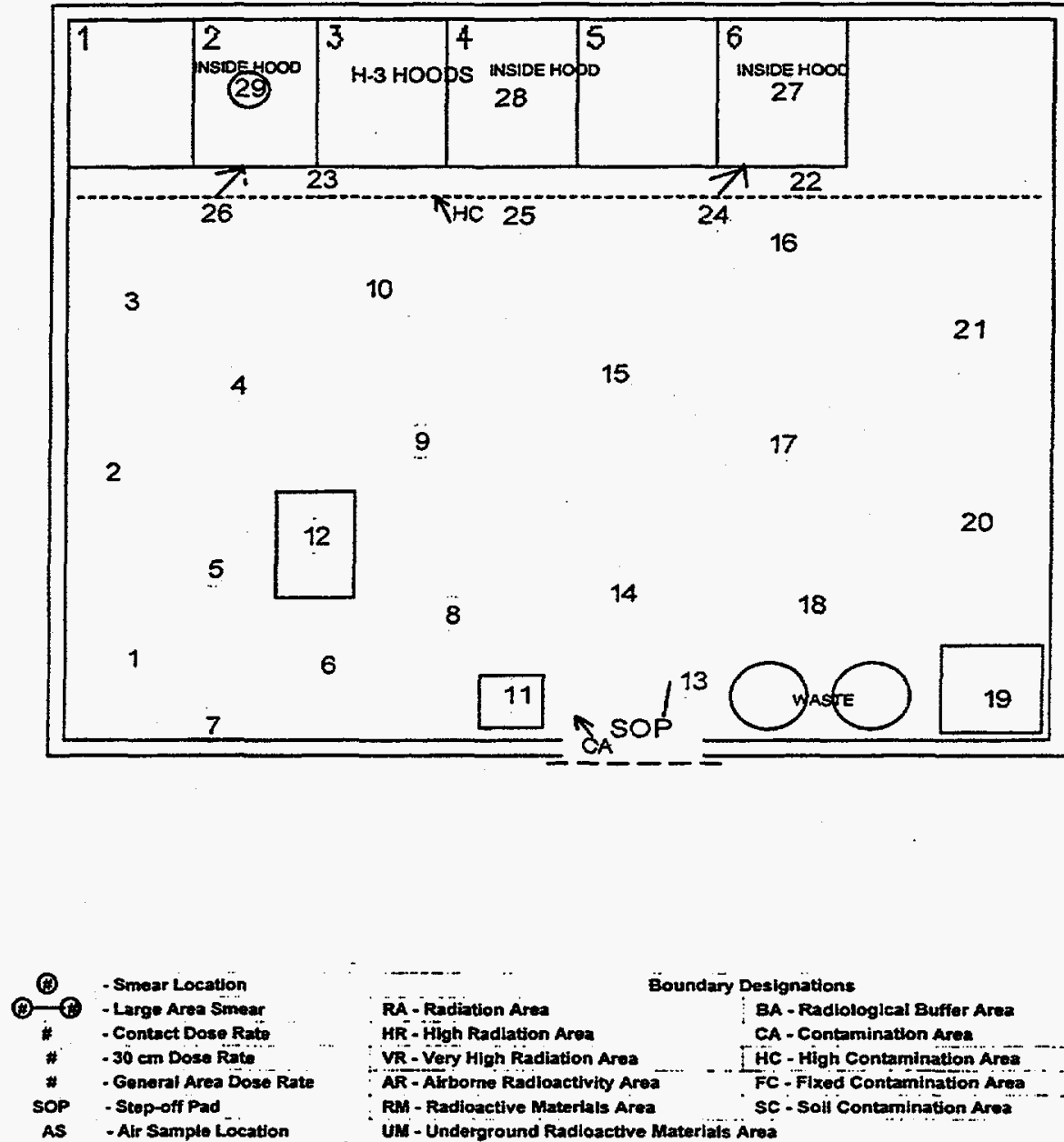

\section{RA - Ridiation Area}

HR - High Radiation Area

Boundary Designätions

VR - Very High Radiation Area

BA - Radlologleal Buffer Area

HC - High Contamination Area -.......

AR - Arborne Radloactivity Area

RM - Radioactive Materials Area

FC - Flxed Contamination Area -

UM - Underground Radloactive Materials Area

Default units are in $\mathrm{mR} / \mathrm{hr}$ and are for open window beta/gamma readings. Letter suffixes with the number indicate

specific radiations: B - Beta (mRad/hr), G - Gamma (mR/hr), N - Neutron (mRem/hr). Boundary designations are

looking from the designations into the zoned area. 


\section{ORNL Radiological Survey Data}



\begin{tabular}{|c|c|c|c|}
\hline & Smear Location & & signations \\
\hline & - Large Area Smear & RA - Radiation Area & BA - Radiological Buffer Area \\
\hline \# & - Contact Dosa Rate & HR - High Radiation Area & CA - Contamination Area \\
\hline & $.30 \mathrm{~cm}$ Dose Rate & VR - Very High Radlation Area & HC - High Contamination Area \\
\hline & - General Area Dose Rate & AR - Airborne Radioactivity Area & FC - Fixed Contamination Area \\
\hline $\mathbf{s}$ & - Stop-off Pad & RII - Radioactive Materials Area & SC - Soll Contamination Area \\
\hline
\end{tabular}

Default units are in $\mathrm{mR} / \mathrm{hr}$ and are for open window beta/gamma readingei. Letter suffixes with the number indicate specific radiations: B - Beta (mRad/hr), G - Gamma (mR/hr), N-Neutron (mRem/hr). Boundary designations are looking from the designations into the zoned area. 


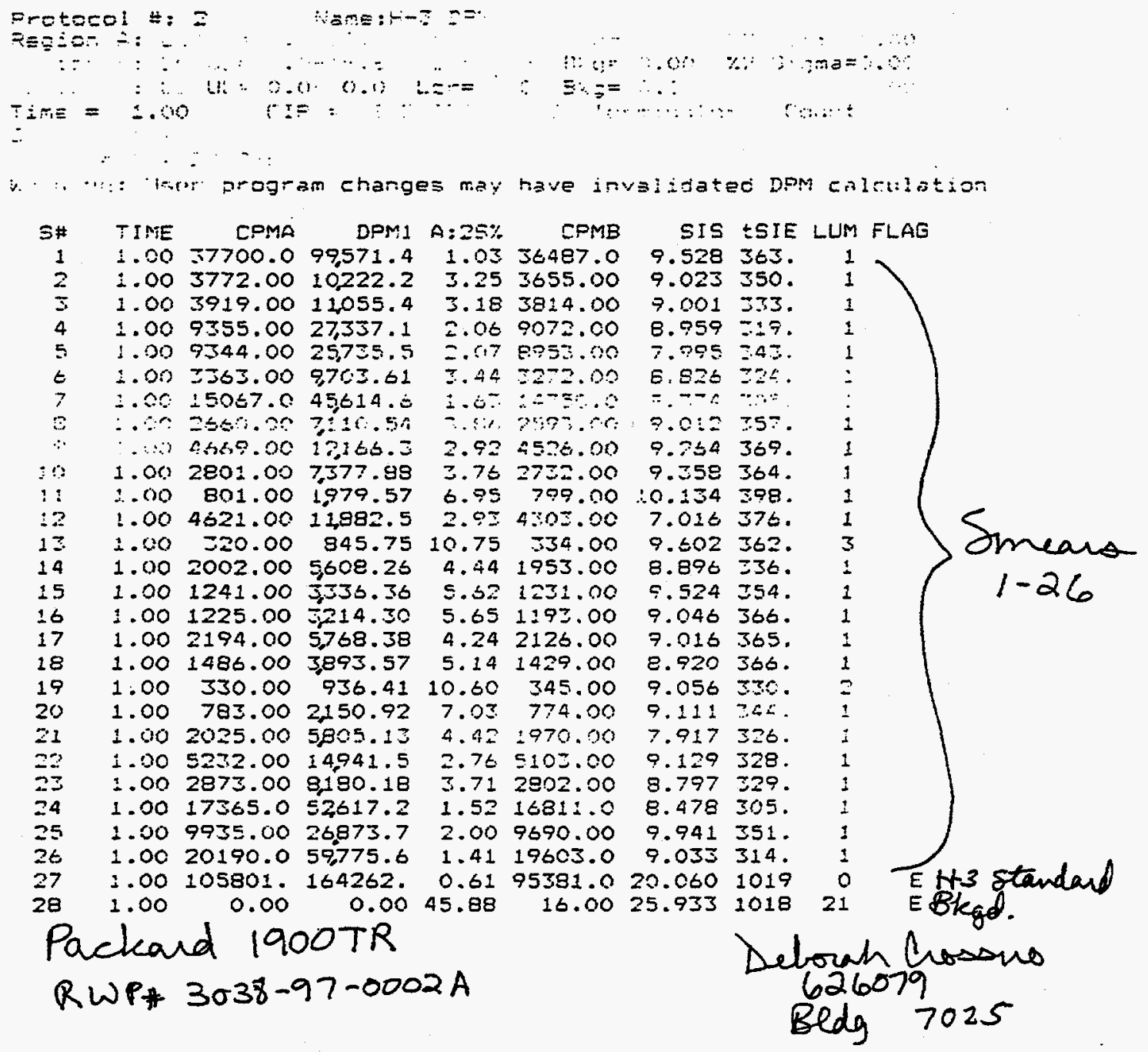









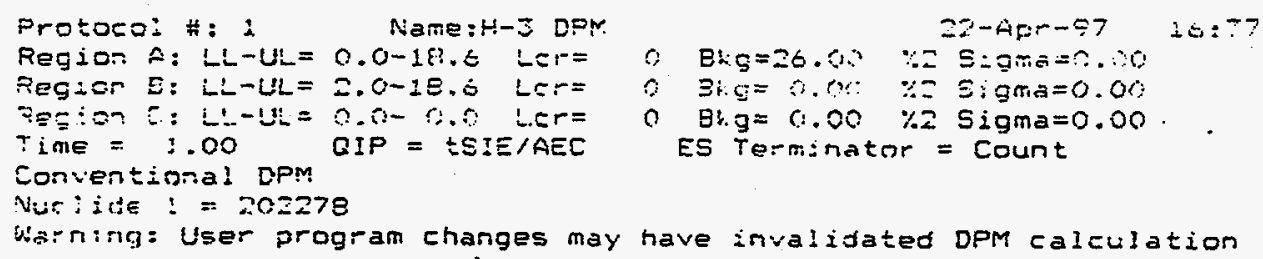



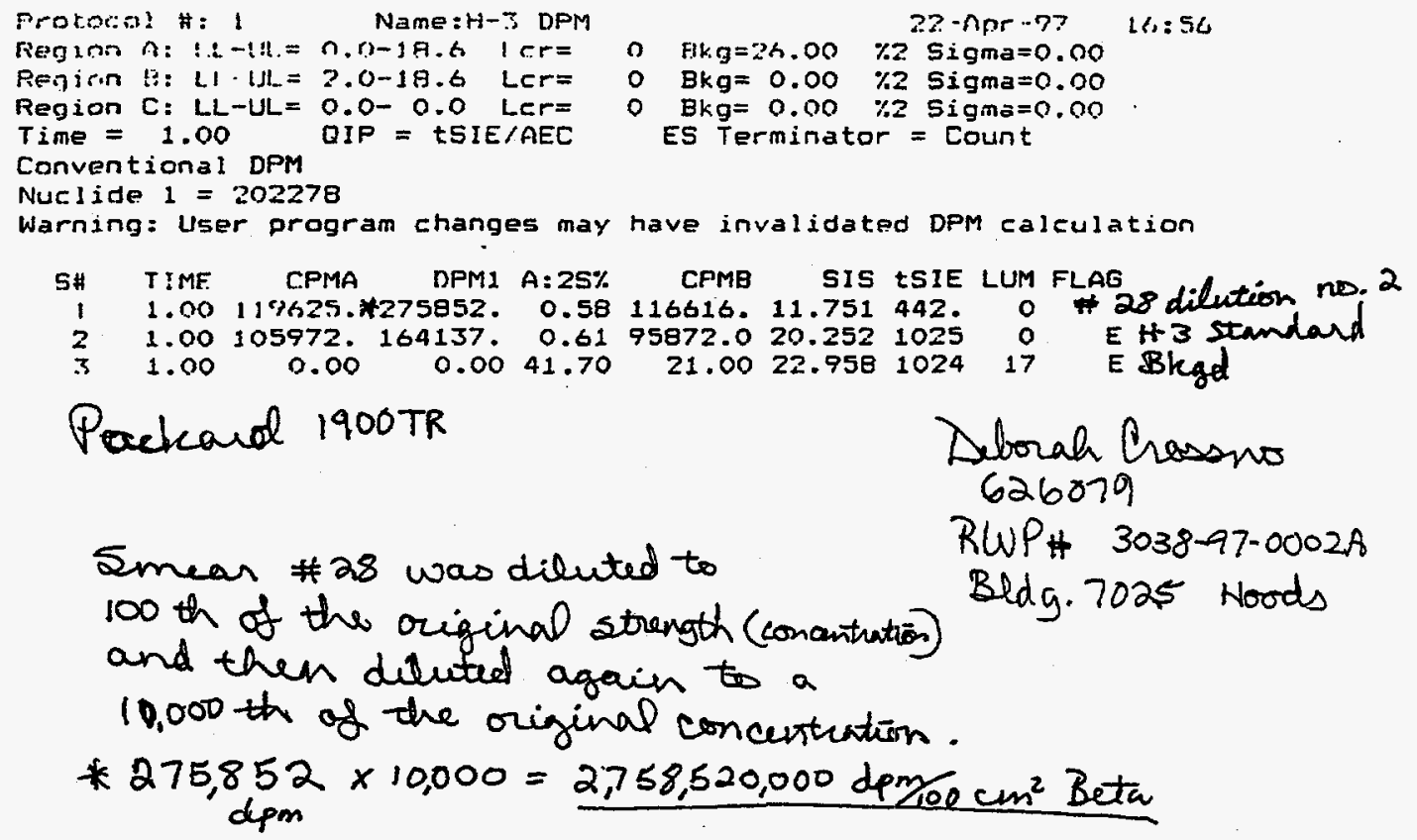


\section{RADIOLOGICAL WORK PERMIT SIGN-IN SHEET}

By my signature below I state that I have read, understand, and will comply with all requirements speciliod in the RWP indicated.

\begin{tabular}{|c|c|c|c|c|c|}
\hline Deborah Crossno & $\begin{array}{l}6260>9 \\
\end{array}$ & $13: 20$ & Trintw & TrME W & TWEIN \\
\hline 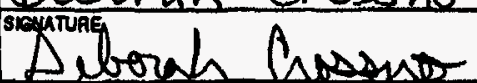 & $3038-97-0002 A$ & $14: 25$ & TME OUT & Trine our & The ow \\
\hline NAME & PROGE NUWBEA & Trume w & Trime & TIMEN & TMER W \\
\hline SIGMTURE & RWP NMMEEA & TIME OVT & True ovi & True ov & TIME ONT \\
\hline NAME & BDOEE NUMEEA & TMEN & Tute & TMEN & TMEN \\
\hline SWMATUनE & AWP NUMBEA & 7ne ov & Trae out & rime ow & frime ovt \\
\hline NAME & OADCE NUTHEEA & TrME W & ruen & THE W & TME N \\
\hline SIGNATUAE & FWP NMEEA & Tine ov & rave out & Trive ov & TIME OUT \\
\hline NAME & OADCE NUMAOEA & rnes & The & TME W & TME W \\
\hline SIGNATUAE & Aिए NundeEA & TIME OUT & Tree ove & THE our & TrMe or \\
\hline NAME & TिOCE NOWDER & The & Timen & Atue & TMEN \\
\hline STMATUAE & 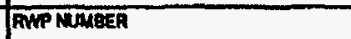 & Thin ovT & TIME OUT & True ov & The ov \\
\hline NAME & BCDCE КUMBEA & THER W & Frape n & TRE W & THEN \\
\hline SIGMTIRE &  & Trist ov & FTME OUT & TIME OUT & TIME OUT \\
\hline NAME & DROSE TOMBEA & THME & Fime on & TRE W & TME N \\
\hline SKCKKTUAE &  & TिME ôt & TIME OUT & 7TME OUT & तिME OUT \\
\hline सAME & DYCGE NUMUEA & TिME & TIME & TIME IN & THMEN \\
\hline SIGMAUURE & FWW NAMBEF & FIME OUT & TREE OUT & TrMe out & TINE OUT \\
\hline
\end{tabular}


RADIOLOGICAL WORK PERMIT SIGN-IN SHEET

By my signature below I state that I have read, understand, and will comply with all requirements specilied in the FWP indicated.

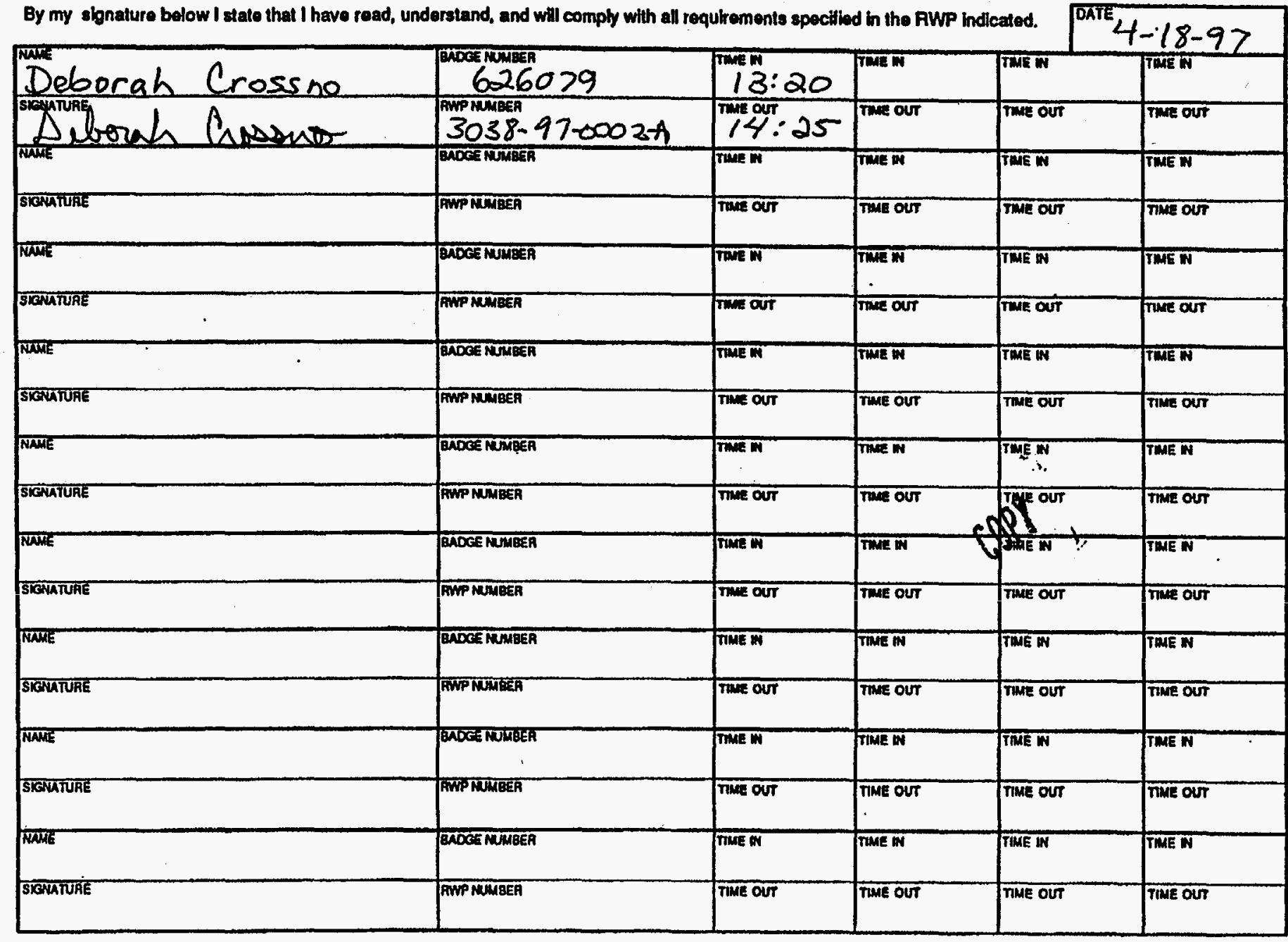









\begin{tabular}{|c|c|c|c|c|c|c|c|c|c|}
\hline \multirow{2}{*}{\multicolumn{3}{|c|}{ 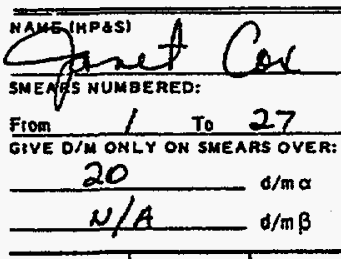 }} & \multirow{2}{*}{ 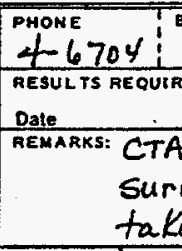 } & 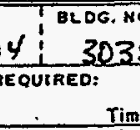 & $\begin{array}{l}\text { BLDG. RO. IAPGSI } \\
3038 \\
\text { RED: }\end{array}$ & \multicolumn{2}{|c|}{$\begin{array}{l}\text { LOCATIOA TSMEARS TAKEN1 } \\
7025 \text { Hood + Surroundings } \\
\text { OATE COUNTED }\end{array}$} & \multicolumn{2}{|c|}{ 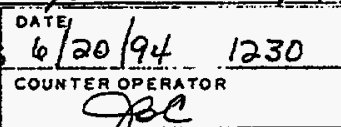 } \\
\hline & & & & $\begin{array}{l}\text { CTA-041 } \\
\text { surrounx } \\
\text { taken }\end{array}$ & $\begin{array}{l}\text { 1, Smee } \\
\text { ding a } \\
\text { on to }\end{array}$ & $\begin{array}{l}\text { irs taken in } \\
\text { rea. Smears } \\
\text { of strippa }\end{array}$ & $\begin{array}{l}\text { Uraniu } \\
\text { inside } \\
\text { able da }\end{array}$ & $\begin{array}{l}\text { um hood } \\
\text { hood a } \\
\text { int. }\end{array}$ & $\begin{array}{l}\text { and } \\
\text { were }\end{array}$ \\
\hline$a$ & $\beta$ & LOCA & $\mathrm{ON}\left({ }^{*}\right)$ & $a$ & $\beta$ & LOCATION $\left(^{*}\right)$ & $a$ & $\beta$ & LOCATION (*) \\
\hline $1-$ & & & & 34 & & & 67 & & \\
\hline 2406 & & & & 35 & & & 68 & & \\
\hline $3 \quad 110$ & & & & 36 & & & 69 & & \\
\hline 4314 & & & & 37 & & & 70 & & \\
\hline \begin{tabular}{|l|l|}
5 & 154 \\
\end{tabular} & & & & 38 & & & 71 & & \\
\hline $5 \quad 31$ & & & & 39 & & & 72 & & \\
\hline 250 & & & & 40 & & & 73 & & \\
\hline $8 \quad 312$ & & & & 41 & & & 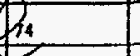 & & \\
\hline $9-$ & & 1 & & 42 & & & 75 & 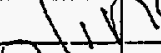 & \\
\hline $10 \quad 53$ & & $\sum n$ & Aaf & 43 & & & 76 & 1 & \\
\hline $11-$ & & see & & 44 & & & 2015 & & \\
\hline $12 \quad 58$ & & & & 45 & & & 78 & & \\
\hline $\begin{array}{ll}13 & 103 \\
\end{array}$ & & & & 45 & & & 79 & & \\
\hline $34 \quad 341$ & & & & 47 & & & 80 & & \\
\hline $15 \quad 93$ & & $\int$ & & 48 & & & 1 & & \\
\hline $15 \quad 89$ & & & & 49 & & & 82 & & \\
\hline $17 \quad 39$ & & & & so & & & 83 & & \\
\hline $\begin{array}{ll}18 \quad 65 \\
\end{array}$ & & Flos & autsid & e & & & 84 & & \\
\hline $19 \quad 50$ & & & hood. & 52 & & & 85 & & \\
\hline $20 \quad 122$ & & & & 53 & & & 86 & & \\
\hline $21-$ & & & & 54 & & & 87 & & \\
\hline $22 \quad 508$ & floer & under & oed & 55 & & & 88 & & \\
\hline 232675 & on d & Efusio & samp & seter hoo & dd & & 89 & & \\
\hline $24 \quad 118$ & under 4 & ood on & iling & 57 & & & 90 & & \\
\hline $\begin{array}{|ll|}25 & 242 \\
\end{array}$ & W. Wa & Lunde & heod & 58 & & & 9 & & \\
\hline 261721 & E. nall & under & ood & 59 & & & 92 & & \\
\hline $27 \quad 1289$ & steel de & te NE & orner un & der hood & & & 93 & & \\
\hline 28 & & & & 61 & & & 94 & & \\
\hline 29 & & & & 62 & & & 95 & & \\
\hline 30 & & & & 63 & & & 96 & & \\
\hline 31 & & & & 64 & & & 97 & & \\
\hline 32 & & & & 65 & & & 98 & & \\
\hline 33 & & & & 66 & & & 99 & & \\
\hline
\end{tabular}




\begin{tabular}{|c|c|c|c|c|c|c|c|c|c|}
\hline \multirow{2}{*}{\multicolumn{3}{|c|}{ 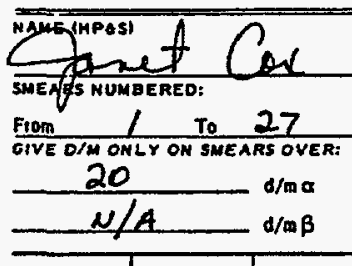 }} & \multicolumn{3}{|c|}{ 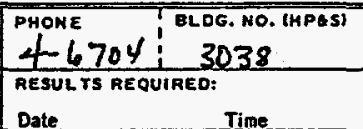 } & \multicolumn{2}{|c|}{$\begin{array}{l}\text { LOCATION ISWEARS SARENI } \\
7025 \text { Hood \& Surrounding: } \\
\text { OATE COUNTED }\end{array}$} & \multicolumn{2}{|c|}{  } \\
\hline & & &  & $\begin{array}{l}\text { CTA-04 } \\
\text { surrour } \\
\text { taken }\end{array}$ & $\begin{array}{l}\text { me } \\
\text { 's sme } \\
\text { on to to }\end{array}$ & $\begin{array}{l}\text { ars taken in } \\
\text { urea. Smears } \\
\text { s of strippe }\end{array}$ & $\begin{array}{l}\text { Urani } \\
\text { inside } \\
\text { able do }\end{array}$ & $\begin{array}{l}\text { um hooc } \\
\text { ant. } \\
\text { aint. }\end{array}$ & $\begin{array}{l}\text { and } \\
\text { were }\end{array}$ \\
\hline$a$ & $\beta$ & LOCA & $10 N(*)$ & $a$ & $\beta$ & LOCATION (*) & $a$ & $\beta$ & LOCATION $\left(^{*}\right)$ \\
\hline $1-$ & & & & 34 & & & 67 & & \\
\hline 2406 & & & & 35 & & & 68 & & \\
\hline 3110 & & & & 36 & & & 69 & & \\
\hline $1 \quad 314$ & & & & 37 & & & 70 & & \\
\hline $\begin{array}{ll}5 & 154 \\
\end{array}$ & & & & 38 & & & 71 & & \\
\hline 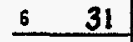 & & & & 39 & & & 72 & & \\
\hline 150 & & & & 160 & & & 3 & & \\
\hline $8 \quad 312$ & & & de & 41 & & & $6 / 4$ & & \\
\hline $9-1$ & & $\frac{1 n}{n}$ & d. & 42 & & & 75 & $y$ & \\
\hline $10 \quad 53$ & & $\sum n$ & Map & 43 & & & 76 & & S \\
\hline $11-$ & & see & & 44 & & & firos & & \\
\hline $12 \quad 58$ & & & & 45 & & & 78 & & \\
\hline $\begin{array}{ll}13 & 103 \\
\end{array}$ & & & & 46 & & & 79 & & \\
\hline $14 \quad 341$ & & 1 & & 47 & & & 80 & & \\
\hline $\begin{array}{ll}15 & 93 \\
\end{array}$ & & 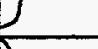 & & 48 & & & 20 & & \\
\hline $\begin{array}{ll}16 \quad 89 \\
\end{array}$ & & ) & & 49 & & & 82 & & \\
\hline $17 \quad 39$ & & & & 50 & & & 133 & & \\
\hline $\begin{array}{ll}18 \quad 65 \\
\end{array}$ & & Floo & outsi & $d g$ & & & 84 & & \\
\hline $19 \quad 50$ & & & hood. & 52 & & & 85 & & \\
\hline $20 \quad 122$ & & & & 53 & & & 86 & & \\
\hline $21-$ & & & & 54 & & & 87 & & \\
\hline $22 \quad 508$ & fleor & ender & cod & 55 & & & 88 & & \\
\hline 232675 & on d & ffusior & pamp. & sefter ho & ad & & 89 & & \\
\hline $24 \quad 118$ & under 4 & ood on & iling & 57 & & & 90 & & \\
\hline $\begin{array}{ll}25 & 242 \\
\end{array}$ & W. Wad & Lunder & heod & 58 & & & 91 & & \\
\hline $26 \quad 1724$ & E. wall & under & & 59 & & & 92 & & \\
\hline $27 \quad 1289$ & steel pat & & orner un & feer hood & & & 93 & & \\
\hline 28 & & . & & 61 & & & 94 & & \\
\hline 29 & & & & 62 & & & 95 & & \\
\hline 30 & & & & 63 & & & 9 & & \\
\hline 31 & & & & 64 & & & 97 & & \\
\hline 32 & & & & 65 & & & 98 & & \\
\hline 33 & & & & 66 & & & 99 & & \\
\hline
\end{tabular}




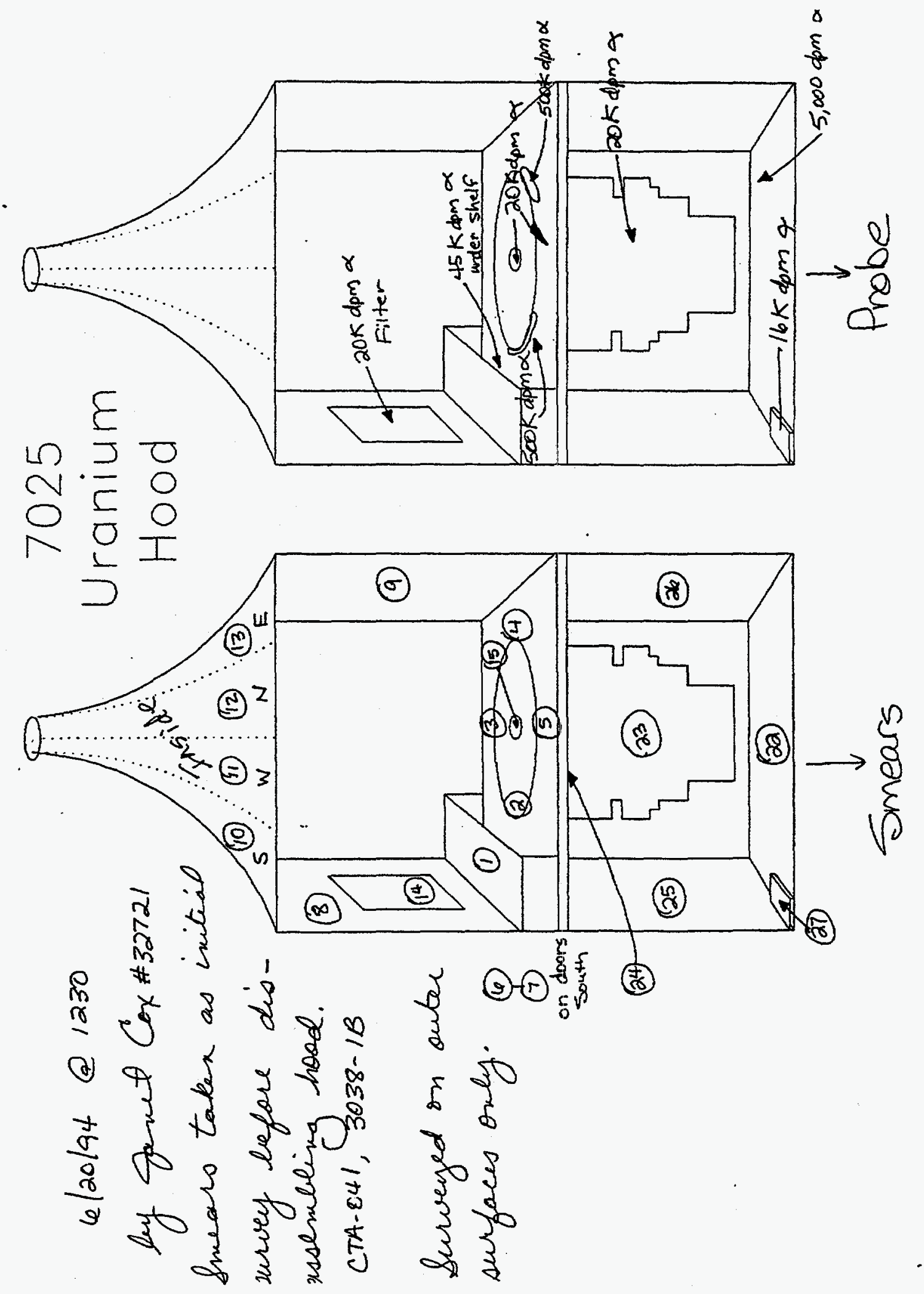






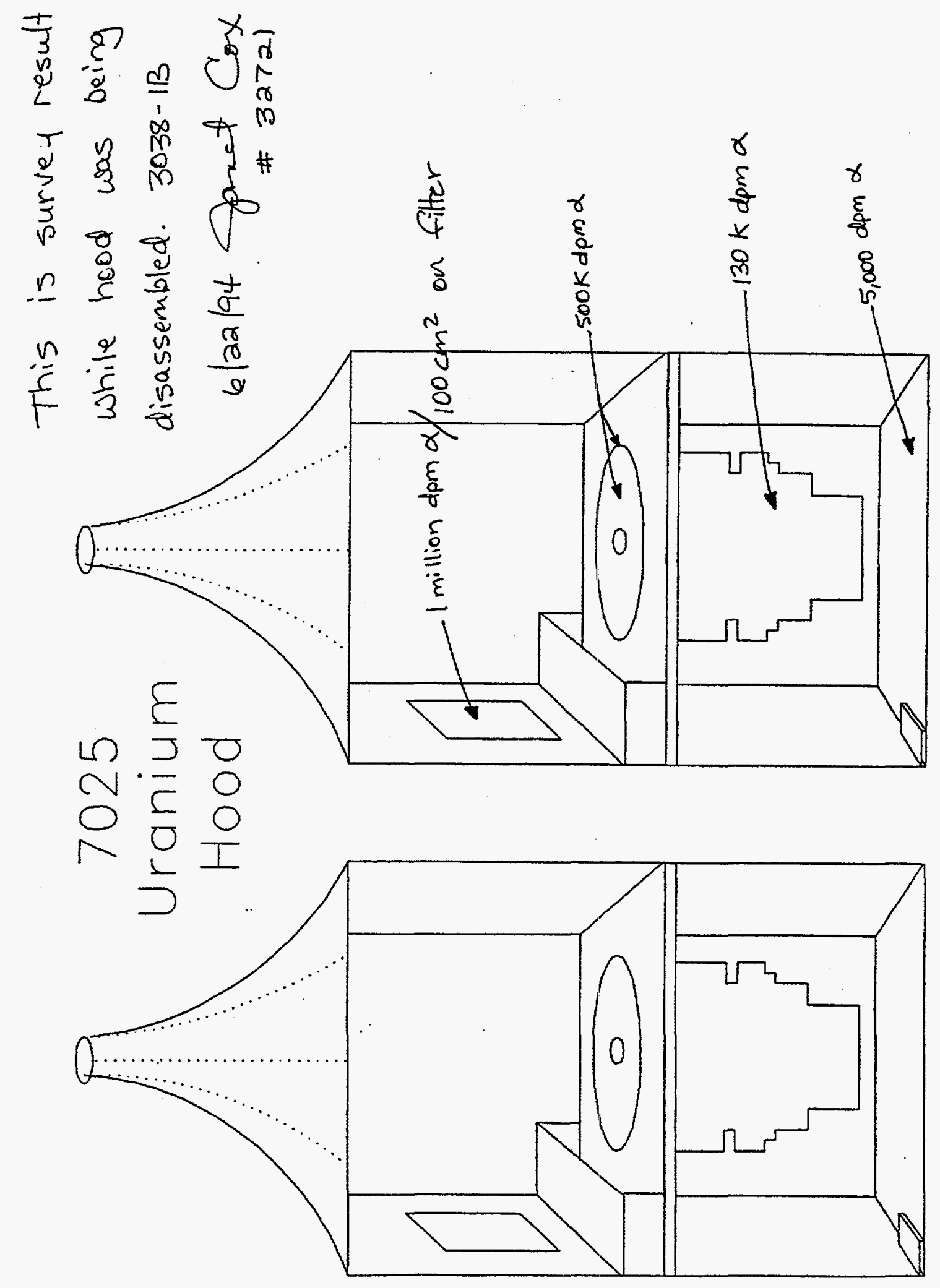


ORNL Radiological Survey Data Slatw $6 / 23 / 44$

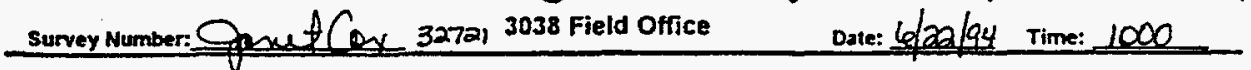

Smears taken on floor after disassembling
Uranium hood:

\section{\begin{tabular}{|l|l|l|}
\hline & $B$ \\
\hline & CTA-041
\end{tabular}}

$\frac{2}{3} x^{2}$

\begin{tabular}{|l|l|}
\hline 1 & \\
\hline 2 & \\
\hline
\end{tabular}

- 960.

$790 / 1$

886

131,

20.655

11. 103/1

$124413 \sqrt{22}$

$23.5045 \mathrm{~m}$

\begin{tabular}{|l|l|}
\hline 14 & 20 \\
\hline 15 & 23 \\
\hline
\end{tabular}

\begin{tabular}{l|l}
35 & 13 \\
\hline
\end{tabular}

\begin{tabular}{|l|l|}
\hline 15 & 15 \\
\hline
\end{tabular}

\begin{tabular}{|l|l|l|}
\hline 17 & \\
\hline 10 &
\end{tabular}

\begin{tabular}{|l|l|}
\hline 15 & 13 \\
\hline & \\
\hline
\end{tabular}

\begin{tabular}{l|l}
\hline 20 & 20 \\
\hline
\end{tabular}

21

2

\begin{tabular}{|l|l|}
\hline 23 & 2 \\
\hline
\end{tabular}

24

\begin{tabular}{|l|l|}
25 & 23 \\
\hline
\end{tabular}

2

2

21

28

$\frac{2}{x}$

I2

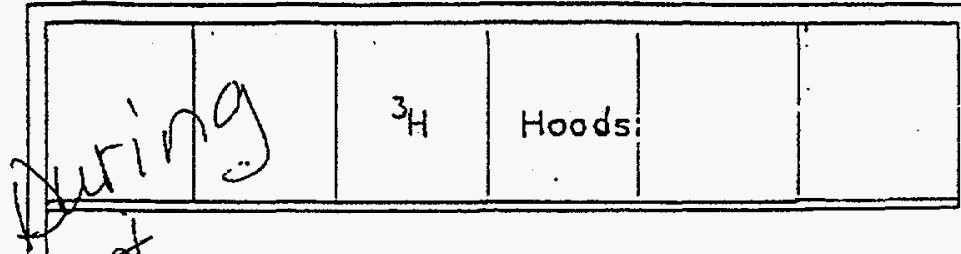

\&

3

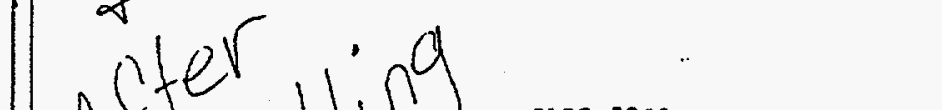

BLDC 7025

(8)
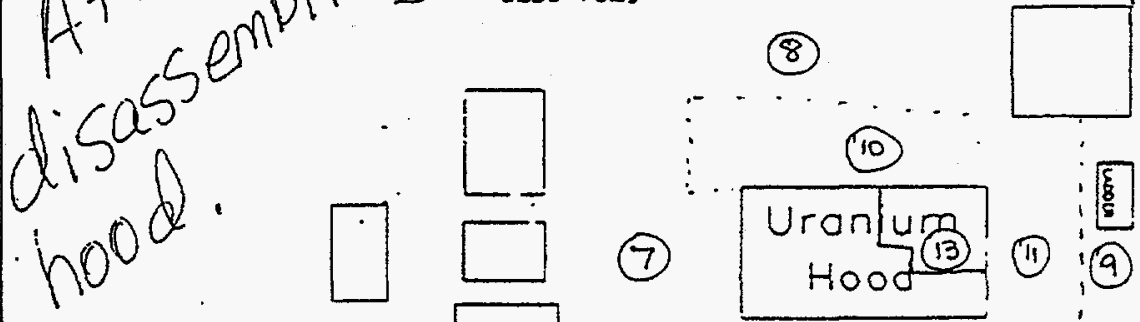<smiles>c1ccccc1</smiles><smiles>C1CCCC1</smiles>

(12)



(6)

CA

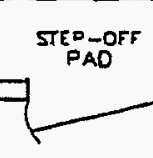

n

TRAVE: LRMER

\begin{tabular}{|c|c|c|c|}
\hline 9 & - Smear Location & \multicolumn{2}{|c|}{ Boundary Designatlons } \\
\hline (3)-9 & - Lrige Area Smear & I RA-Radiation Area & EA - Radiological Buffer Area \\
\hline 票 & - Contact Dosa Rate & HR - High Radiallon Area & CA - Contamination Area \\
\hline$\pi$ & $-30 \mathrm{~cm}$ Dore Rate & VR - Very High Radiation Area & HC - High Contamination Area \\
\hline$\#$ & - Ceneral Area Dosa Rate & AR - Aliborne Rodlosetivity Ares & FC - Fixed Contamination Ares \\
\hline SOP] & - Step-off Pad & RM - Rodianctlve Materials Area & SC - Solt Contamination Area \\
\hline
\end{tabular}
As - Ar sample Loeation $\quad$ UM . Underground Radioactive Materials Area

Default units are in $\mathrm{mR} / \mathrm{hr}$ and are for open window beta/gamma readings. Letter suffixes with the number indicate apeciffe radiatlons: B - Beta (mRad/hr), G - Gamma (mR/hr), N - Neutron (mRem/hr). Boundary designatlons are looking trom the designations into the zoned area. 

ATTACHMENT 6

ADMINISTRATIVE TURNOVER

PACKAGE CHECKLIST 



\begin{tabular}{clc}
\hline Item Number & \multicolumn{1}{c}{ Document } & Applicable ? \\
\hline 1 & FDPR & Yes \\
2 & Emergency Response Plan & No \\
3 & Safety Documentation (Category III or greater) & No \\
4 & Regulatory Compliance Documentation & No \\
5 & Interagency Agreements Documentation & No \\
6 & Existing Permit Documentation & No \\
7 & Corrective Action Documentation & No \\
8 & Postdeactivation Punchlist & No \\
9 & Deactivation Locks and Keys & Yes \\
\hline
\end{tabular}



ATTACHMENT 7

TECHNICAL TURNOVER

PACKAGE CHECKLIST 

Technical Turnover Package Checklist

\begin{tabular}{clc}
\hline Item Number & \multicolumn{1}{c}{ Document } & Applicable ? \\
\hline 1 & End Point Determination Report & No \\
2 & End Points Completion Report & No \\
3 & End Point Technical Information & No \\
4 & Deactivation Work Plans & No \\
5 & Updated Facility Drawings (arrangement, PID, Loop, etc.) & No \\
6 & "As Left" Photos of Spaces and Major Equipment & Yes \\
7 & Hazardous Material Inventory and Survey & No \\
8 & Safeguards and Security Documentation & No \\
9 & Chemical Substance Inventory and Survey & No \\
10 & Radioactive Materials Inventory and Survey & Yes \\
11 & Facility Soil, Surface Water, and Groundwater Condition & No \\
\hline
\end{tabular}



ATTACHMENT 8

S\&M TURNOVER

PACKAGE CHECKLIST 



\begin{tabular}{clc}
\hline Item Number & \multicolumn{1}{c}{ Document } & Applicable ? \\
\hline 1 & Postdeactivation S\&M Plan & Yes \\
2 & Postdeactivation S\&M Updated Effluent Monitoring Plan & No \\
3 & Postdeactivation S\&M Updated Safety Equipment List & No \\
4 & Postdeactivation S\&M Procedures & Yes \\
5 & Postdeactivation S\&M Recommendations & No \\
6 & Mothballed Systems Lay-up and Restart Documentation & No \\
\hline
\end{tabular}




\section{DISTRIBUTION}

1. L. V. Asplund

2. W. D. Brickeen

3. R. A. Brown

4. T. W. Burwinkle

5. K. Constant

6-15. R. E. Eversole

17. K. W. Haff

18. S. A. Herron

19. L. L. Kaiser

20. T. M. Koepp

21. P. T. Owen

22. L. D. Owens

23. B. D. Patton

24. L. B. Raulston

25. Central Research Library

26. File-EMEF DMC-RC 
